DiRECTEURS DE LA PUBLICATION / PUBLICATION DIRECTORS:

Bruno David, Président du Muséum national d'Histoire naturelle

Étienne Ghys, Secrétaire perpétuel de l'Académie des sciences

RÉDACTEURS EN CHEF / EDITORS-IN-CHIEF: Michel Laurin (CNRS), Philippe Taquet (Académie des sciences)

AssistANTE DE RÉDACTION / AssistANT EDITOR: Adenise Lopes (Académie des sciences; cr-palevol@academie-sciences.fr)

MISE EN PAGE / PAGE LAYOUt: Audrina Neveu (Muséum national d'Histoire naturelle; audrina.neveu@mnhn.fr)

RÉVISIONS LINGUISTIQUES DES TEXTES ANGLAIS / ENGLISH LANGUAGE REVISIONS: Kevin Padian (University of California at Berkeley)

RÉDACTEURS ASSOCIÉS / ASSOCIATE EDITORS ( ${ }^{*}$, took charge of the editorial process of the article/a pris en charge le suivi éditorial de l'article):

Micropaléontologie/Micropalaeontology

Maria Rose Petrizzo (Università di Milano, Milano)

Paléobotanique/Palaeobotany

Cyrille Prestianni (Royal Belgian Institute of Natural Sciences, Brussels)

Métazoaires/Metazoa

Annalisa Ferretti* (Università di Modena e Reggio Emilia, Modena)

Paléoichthyologie/Palaeoichthyology

Philippe Janvier (Muséum national d'Histoire naturelle, Académie des sciences, Paris)

Amniotes du Mésozoïque/Mesozoic amniotes

Hans-Dieter Sues (Smithsonian National Museum of Natural History, Washington)

Tortues/Turtles

Juliana Sterli (CONICET, Museo Paleontológico Egidio Feruglio, Trelew)

Lépidosauromorphes/Lepidosauromorphs

Hussam Zaher (Universidade de São Paulo)

Oiseaux/Birds

Eric Buffetaut (CNRS, École Normale Supérieure, Paris)

Paléomammalogie (mammifères de moyenne et grande taille)/Palaeomammalogy (large and mid-sized mammals)

Lorenzo Rook (Università degli Studi di Firenze, Firenze)

Paléomammalogie (petits mammifères sauf Euarchontoglires)/Palaeomammalogy (small mammals except for Euarchontoglires)

Robert Asher (Cambridge University, Cambridge)

Paléomammalogie (Euarchontoglires)/Palaeomammalogy (Euarchontoglires)

K. Christopher Beard (University of Kansas, Lawrence)

Paléoanthropologie/Palaeoanthropology

Roberto Macchiarelli (Université de Poitiers, Poitiers)

Archéologie préhistorique/Prehistoric archaeology

Marcel Otte (Université de Liège, Liège)

RÉFÉRÉS / REVIEWERS: https://sciencepress.mnhn.fr/fr/periodiques/comptes-rendus-palevol/referes-du-journal

COUVERTURE / COVER:

Made from figures from the article. Map: paleogeographic reconstruction of the Early Devonian (400 Ma). Modified from Rustán (2016).

Comptes Rendus Palevol est indexé dans / Comptes Rendus Palevol is indexed by:

- Cambridge Scientific Abstracts

- Current Contents ${ }^{\circledR}$ Physical

- Chemical, and Earth Sciences ${ }^{\circledR}$

- ISI Alerting Services ${ }^{\circledR}$

- Geoabstracts, Geobase, Georef, Inspec, Pascal

- Science Citation Index ${ }^{\circledR}$, Science Citation Index Expanded ${ }^{\circledR}$

- Scopus ${ }^{\circledR}$.

Les articles ainsi que les nouveautés nomenclaturales publiés dans Comptes Rendus Palevol sont référencés par / Articles and nomenclatural novelties published in Comptes Rendus Palevol are registered on:

- ZooBank ${ }^{\circledR}$ (http://zoobank.org)

Comptes Rendus Palevol est une revue en flux continu publiée par les Publications scientifiques du Muséum, Paris et l'Académie des sciences, Paris Comptes Rendus Palevol is a fast track journal published by the Museum Science Press, Paris and the Académie des sciences, Paris

Les Publications scientifiques du Muséum publient aussi / The Museum Science Press also publish:

Adansonia, Geodiversitas, Zoosystema, Anthropozoologica, European Journal of Taxonomy, Naturae, Cryptogamie sous-sections Algologie, Bryologie, Mycologie.

L'Académie des sciences publie aussi / The Académie des sciences also publishes:

Comptes Rendus Mathématique, Comptes Rendus Physique, Comptes Rendus Mécanique, Comptes Rendus Chimie, Comptes Rendus Géoscience, Comptes Rendus Biologies.

Diffusion - Publications scientifiques Muséum national d'Histoire naturelle

CP 41 - 57 rue Cuvier F-75231 Paris cedex 05 (France)

Tél. : 33 (0)1 40794805 / Fax: 33 (0)1 40793840

diff.pub@mnhn.fr / https://sciencepress.mnhn.f

Académie des sciences, Institut de France, 23 quai de Conti, 75006 Paris.

(C) This article is licensed under the Creative Commons Attribution 4.0 International License (https://creativecommons.org/licenses/by/4.0/)

ISSN (imprimé / print): 1631-0683/ ISSN (électronique / electronic) : 1777-571X 


\title{
New dalmanitid trilobite taxa from the Lower Devonian of Argentina: comments on spinosity in endemic taxa from southern high paleolatitudes
}

\author{
Enrique A. RANDOLFE \\ Centro de Investigaciones en Ciencias de la Tierra: Consejo Nacional de Investigaciones \\ Científicas y Técnicas-Universidad Nacional de Córdoba, \\ Avenida Vélez Sarsfield 1611, Córdoba (X5016GCA) (Argentina) \\ enrique.randolfe@gmail.com (corresponding author)
}

Juan José RUSTÁN

Centro de Investigaciones en Ciencias de la Tierra: Consejo Nacional de Investigaciones Científicas y Técnicas-Universidad Nacional de Córdoba, Avenida Vélez Sarsfield 1611, Córdoba (X5016GCA) (Argentina) and Universidad Nacional de La Rioja, Avenida Luis M. de la Fuente S/N, Ciudad Universitaria de la Ciencia y de la Técnica, La Rioja (F5300) (Argentina) juanjorustan@gmail.com

Arnaud BIGNON Centro de Investigaciones en Ciencias de la Tierra: Consejo Nacional de Investigaciones Científicas y Técnicas-Universidad Nacional de Córdoba, Avenida Vélez Sarsfield 1611, Córdoba (X5016GCA) (Argentina) arnaudbignon@yahoo.fr

Submitted on 4 May 2020 | Accepted on 3 August 2020 | Published on 12January 2022

KEY WORDS

Dalmanitidae Devonian,

Malvinokaffric, predation,

spines

trilobite

new genera,

new species.

Randolfe E. A., Rustán J. J. \& Bignon A. 2022. - New dalmanitid trilobite taxa from the Lower Devonian of Argentina: comments on spinosity in endemic taxa from southern high paleolatitudes. Comptes Rendus Palevol 21 (2): 17-38. https://doi.org/10.5852/cr-palevol2022v21a2

\section{ABSTRACT}

Three new Lower Devonian dalmanitid trilobite taxa are recognized from the Talacasto Formation in the Precordillera Basin, Argentina, which includes two monospecific genera (Ivanites leonorae n. gen., n. sp. and Aguaditaspis mediaspina n. gen., n. sp.), and one additional new genus and species left in open nomenclature. These taxa combine characters of the subfamilies Dalmanitinae Vogdes, 1890 and Synphoriinae Delo, 1935, challenging their taxonomic distinction. Forty percent of the dalmanitids from high paleolatitudinal basins from southwestern Gondwana (Malvinokaffric) exhibit non-homologous dorsal spinosity. Aguaditaspis mediaspina n. gen., n. sp. shares similar spines with Trypaulites calypso (Hall, 1861). The unnamed new genus resembles the spinosity of endemic Malvinokaffric dalmanitids, like Dalmanitoides Delo, 1935 and Fenestraspis Braniša \& Vaněk, 1973. Considered defensive, the recorded spinosity along with putative sublethal-attack marks, suggest higher predation pressure than previously thought at high paleolatitudes. This evidence is in accordance with some hypothesis on rising predation pressure in the mid-Paleozoic marine ecosystems. 


\section{MOTS CLÉS \\ Dalmanitidae, Dévonien, Malvinokaffric, prédation, épines, trilobite, genres nouveaux, espèces nouvelles.}

\begin{abstract}
RÉSUMÉ
Nouveaux taxons de trilobites dalmanitidés du Dévonien inférieur d'Argentine : discussion sur les épines des taxons endémiques de hautes paléolatitudes australes.

Trois nouveaux taxons de trilobites dalmanitidés provenant de la formation Talacasto, du Dévonien inférieur, sont identifiés dans le bassin de la Précordillère, en Argentine. Deux nouveaux genres monospécifiques sont décrits (Ivanites leonorae n. gen., n. sp. et Aguaditaspis mediaspina n. gen., n. sp.). Un spécimen additionnel, correspondant probablement à un nouveau genre et espèce, est laissé en nomenclature ouverte. Ces taxons présentent la combinaison de caractères diagnostiquant les sous-familles Dalmanitinae Vogdes, 1890 et Synphoriinae Delo, 1935, remettant en cause leur distinction taxonomique. Quarante pour cent des dalmanitidés de hautes paléolatitudes des bassins sud-ouest du Gondwana (Malvinokaffrik) montrent des épines dorsales non homologues. Aguaditaspis mediaspina n. gen., n. sp. partage des épines avec Trypaulites calypso (Hall, 1861). Le genre laissé en nomenclature ouverte a des épines proches de celles des dalmanitidés endémiques du Domaine Malvinokaffric, tels que Dalmanitoides Delo, 1935 et Fenestraspis Braniša \& Vaněk, 1973. Les épines, considérées comme défensives, associées à l'enregistrement de marques probables d'attaques sublétales, suggèrent une contrainte de prédation plus importante sous les hautes paléolatitudes qu'on ne le supposait précédemment. Ces données soutiennent l'hypothèse d'une augmentation de la prédation dans les écosystèmes du Paléozoïque moyen.
\end{abstract}

\section{INTRODUCTION}

The dalmanitid trilobites, abundant worldwide and diverse in the Silurian-Devonian, attracted comparatively little attention in basins of southwestern Gondwana. In spite of this, Eldredge \& Ormiston (1979) had considered an important diversification of this family in these basins (basins of the Malvinokaffric Realm). At that time most of the information derived from a number of main works (e.g. Clarke 1890; Kozłowski 1923; Swartz 1925; Wolfart 1968) which assigned species to classic genera like Dalmanites Barrande, 1852 or Odontochile Hawle \& Corda, 1847. Several new genera, endemic in this area, were subsequently erected by Braniša \& Vaněk (1973). In recent years, those genera were revised with focus on morphological characters rare for dalmanitids (Edgecombe 1993; Carvalho \& Fonseca 2007; Holloway \& Carvalho 2009, 2010; Rustán \& Vaccari 2012). These characters include robust dorsal spines (Dalmanitoides Delo, 1935; and Fenestraspis Braniša \& Vaněk, 1973), a distinctly inflated frontal lobe (Francovichia Braniša \& Vaněk, 1973), bifid caudal spines (Chacomurus Braniša \& Vaněk, 1973) and intersegmental fenestrae (Fenestraspis). With these previous works, it became clear that Malvinokaffric dalmanitids are important for diversification studies because of those distinctive characters.

In this contribution, we report new dalmanitids from the Precordillera Basin, Argentina, which is the main source of well-known Devonian trilobite records from Argentina (Rustán et al. 2011a). Three new genera are recognized, two formally erected and one left in open nomenclature, including some specimens only preliminarily reported in previous contributions (Rustán 2011, 2016).

Accounting for a diversification of the family, some of these new dalmanitid taxa reported herein exhibit clear dorsal spines, an unusual character for the family, documented only in a few
Devonian taxa. Hence, we perform a preliminary analysis of spinosity in dalmanitid trilobites of southern Gondwana. The evolutionary/ecological meaning of these spines, generally considered as defensive structures in trilobites (Clarkson \& Ahlberg 2002; Pates \& Bicknell 2019), is taken as an indirect proxy of predation pressure, together with other additional clues such as signs of failed attacks.

Various data suggest a latitudinal gradient of predation in marine ecosystems with higher predation pressure at lower paleolatitudes (Dudley \& Vermeij 1978; Leighton 1999; Harper \& Peck 2016), hence demonstrating the significance of our new evidence from high paleolatitudes during the Devonian.

\section{GEOLOGICAL SETTING}

The sampled unit is the Lower Devonian Talacasto Formation (Padula et al. 1967), mainly exposed in the Central Precordillera in the San Juan Province, Argentina (Fig. 1B), although isolated outcrops are also known from the northernmost extension of the Precordillera, in the Sierra de las Minitas (Fig. 1A), La Rioja Province, Argentina (Rustán et al. 2011a). This formation is composed of a marine succession of intensely bioturbated greenish-gray mudstones with intercalated sandstones. It begins with Lochkovian dark, fine-grained, muddy levels, passing upwards into Pragian and Emsian sandy levels. In the type locality at Quebrada de Talacasto, in San Juan Province, the formation reaches around $300 \mathrm{~m}$ in thickness, but a maximum of more than $1000 \mathrm{~m}$ is recorded in the north at the Loma de los Piojos section, near Jáchal city (Fig. 2).

The Talacasto Formation represents a muddy shelf depositional system developed during a highstand (Astini 1991). The unit covers the (mainly) upper Silurian shelf succession of the Los Espejos Formation (Cuerda 1965) and is overlain by 


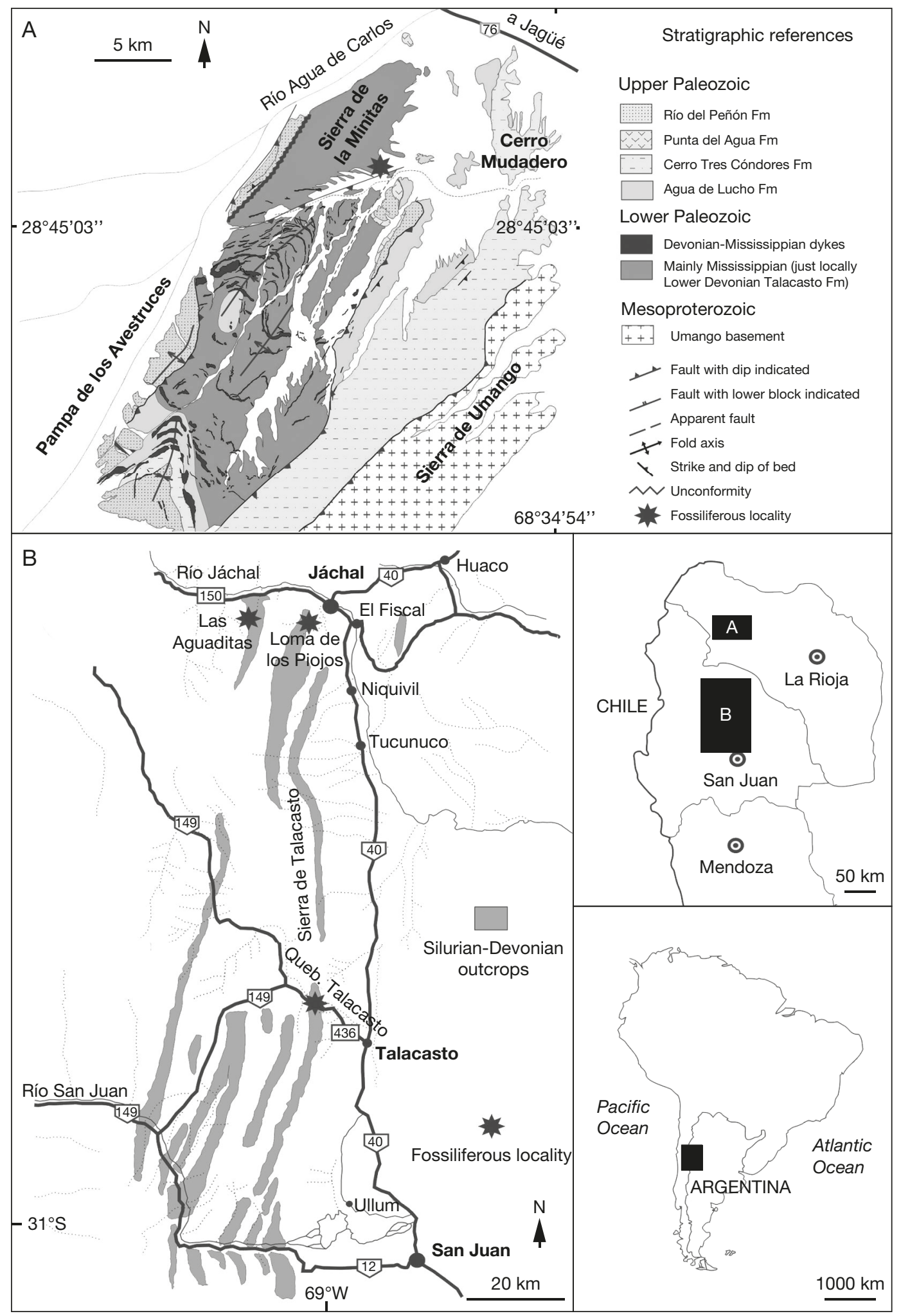

FIG. 1. - Locations of Lower Devonian fossil localities (black stars) in the Precordillera Basin, Argentina: A, detail of the outcrops at Sierra de las Minitas, La Rioja Province; B, detail of the outcrops in San Juan Province. Modified from Cichowolski \& Rustán (2017).

a turbiditic system of the Lower to probably Middle Devonian Punta Negra Formation (Bracaccini 1949; Bustos \& Astini 1997; García Muro et al. 2018). The Talacasto Formation is the source of most Devonian macrofossils from Argentina, including brachiopods, trilobites, bivalves, gastropods, cephalopods, echinoderms, corals, tentaculitids, ostracods, hyoliths, conulariids, and scarce plant remains of uncertain assignation (Rustán \& Balseiro 2016). 
Based on brachiopod and palynological information (Benedetto et al. 1992; Herrera 1993; Racheboeuf \& Herrera 1994; Herrera \& Bustos 2001; García Muro et al. 2017, 2018), the Talacasto Formation spans from the Lochkovian to the Pragian, with Emsian ages recently discussed (García Muro et al. 2018). Except for a few localities, the base of the Devonian is usually missing due to a discontinuity with the Los Espejos Formation (Benedetto et al. 1992; Carrera et al. 2013; García Muro et al. 2017).

\section{FOSSILIFEROUS LOCALITIES}

Quebrada de las Aguaditas, Sierra de los Blanquitos, approximately $12 \mathrm{~km}$ southwest of Jáchal city (Fig. 1B). The fossiliferous interval, about $100 \mathrm{~m}$ in thickness, corresponds to the Lochkovian-Pragian dark lower muddy stratigraphic interval of the Talacasto Formation. Fossils were collected in the proximity of GPS waypoint 30¹8'22.95”S, 68 50'12.15”W, preserved in dark grey to black nodules (the same that contain the phacopid Echidnops taphomimus Rustán \& Balseiro, 2016).

Loma de los Piojos, a classical section located about $8 \mathrm{~km}$, southwest of Jáchal city (García Muro et al. 2018). Only one specimen originates from this locality, preserved inside a nodule from the Lochkovian-Pragian greenish lower muddy interval at GPS waypoint $30^{\circ} 17^{\prime} 45.6^{\prime \prime} \mathrm{S}, 68^{\circ} 46^{\prime} 27.8^{\prime \prime} \mathrm{W}$.

Quebrada de Talacasto, the type section of the Talacasto Formation. It is located over the provincial road route 436 , about $60 \mathrm{~km}$ to the northwest of San Juan city. The cephalon from this locality is preserved in grey-bluish fine-grained sandstones, from the middle-upper part of the unit. Palynological data of this locality suggests a Pragian age (García Muro et al. 2018).

Sierra de las Minitas is a mountain region located to the west of Jagüe town, at north-west of the Province La Rioja, Argentina (Fig. 1A). The geology of this locality is complex, because stratigraphy of several folding and faulting stages. A portion of the Lochkovian-Pragian lower muddy interval of the Talacasto Formation locally crops out here, which is equivalent to that of the Quebrada de las Aguaditas on the basis of lithology and fauna (Rustán et al. 2011a; Rustán \& Balseiro 2016). Specimens were collected in proximity of the GPS waypoints $28^{\circ} 42^{\prime} 50^{\prime \prime} \mathrm{S}$, $68^{\circ} 39^{\prime} 29^{\prime \prime} \mathrm{W}$ and $28^{\circ} 42^{\prime} 43.8^{\prime \prime} \mathrm{S}, 68^{\circ} 39^{\prime} 40.9^{\prime \prime} \mathrm{W}$

\section{MATERIAL AND METHODS}

Material is housed at the Centro de Investigaciones en Ciencias de la Tierra (CONICET-Universidad Nacional de Córdoba), numbered with the prefix CEGH-UNC; and the Museo de Paleontología of the Universidad Nacional de Córdoba, numbered with the prefix CORD-PZ, both in Córdoba city. Specimens from Sierra de las Minitas are housed in the collection of Museo de Ciencias Antropológicas y Naturales of the Universidad Nacional de La Rioja, La Rioja, numbered with the prefix PULR.

Specimens were prepared using pneumatic vibro-tools (micro jacks) and needles under binocular microscope. Fossils were covered with black Chinese ink. In the case of external molds, rubber casts were obtained and colored in black. Fossils and rubber casts were coated with ammonium chloride sublimated prior to photography. Specimens were photographed using a digital camera Canon Power Shot S50 mounted on a binocular loupe Leica MZ75.

\section{AbBREVIATIONS}

Technical terms are abbreviated as traditional in trilobite descriptions: exsag. exsagittal/exsagittally;

sag. $\quad$ sagittal/sagittally;

tr. transversal/transversely.

\section{SYSTEMATIC PALEONTOLOGY}

\section{REMARKS}

In the description of the pygidial terminal piece, we counted any furrow that indicates segmentation, including those barely impressed (see discussions in Campbell 1977). Open nomenclature follows criteria by Bengtson (1988). Morphological structure denomination follows Whittington \& Kelly (1997).

Order PHACOPIDA Salter, 1864

Suborder PHACOPINA Struve in Moore, 1959

Superfamily DaLmanitoidea Vogdes, 1890

Family Dalmanitidae Vogdes, 1890

\section{REMARKS}

Subfamilies of Dalmanitidae have long been discussed. For Silurian and Devonian taxa, the most widely accepted groups include Dalmanitinae Vogdes, 1890 and Synphoriinae Delo, 1935. In particular, Synphoriinae was considered either a distinct family (Delo 1935; Lespérance 1975), or a subfamily closely related to Dalmanitinae (Lespérance \& Bourque 1971; Holloway 1981; Edgecombe 1993; Holloway \& Carvalho 2009). Currently, the proposals of subfamilies by Holloway (1981) along with characters proposed by Campbell (1977) are the most frequently used for classification. Dalmanitinae is defined mainly by apodems of $\mathrm{S} 1$ equidistant between those of $\mathrm{SO}$ and S2; a cephalic epiborder furrow; large exsag. eyes extending close to the posterior border furrow; a well-developed pygidial border; a pygidium with 12 or more axial rings; and anterior pleural bands sloping steeply posteriorly and posterior ones sloping more gently anteriorly on the pygidial pleural furrows which are asymmetrical in cross section. On the other hand, Synphoriinae is mainly supported by the exsagittal distance between S1 and S2 apodems 1.5 times longer than between S1 and SO apodems; S2 reduced tr. tending to be subcircular; shorter exsag. eyes; pygidium without a well-defined border; pygidial pleural bands of equal length exsag. with a symmetrical pleural furrow in cross section; and apodemal pits of inter-ring furrows without contacting axial furrows on the pygidium. However, some taxonomic issues remain unsolved, so that several genera cannot be clearly assigned to a subfamily based on their current definitions (Edgecombe 1991; Rustán \& Vaccari 2012). For example, a number of characters is demonstrably variable within a single genus, such as the spacing between apodems of the glabellar furrows in Lygdozoon Holloway, 1981, 


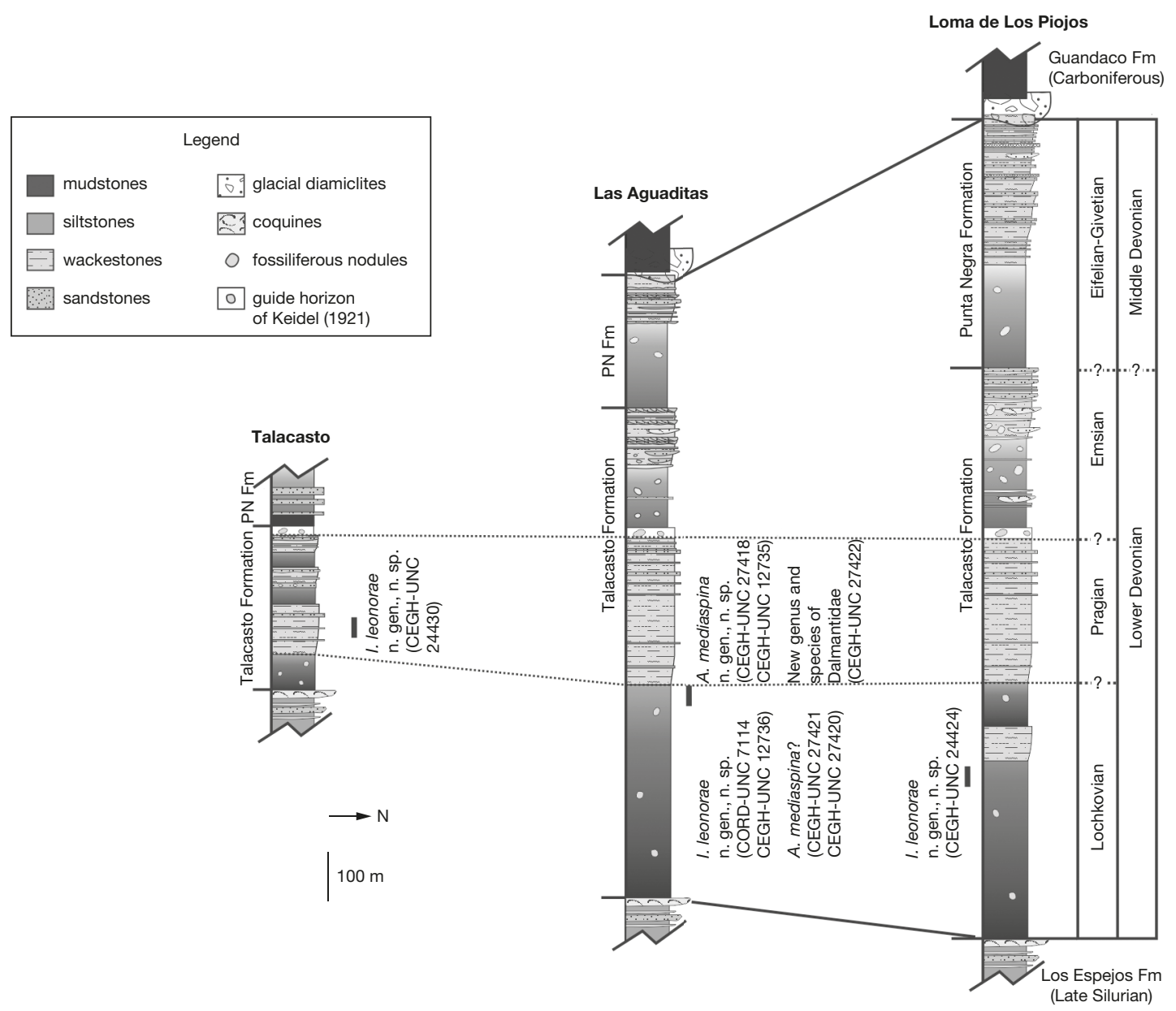

FIG. 2. - Stratigraphic sections of the Talacasto Formation, showing its diachronic top and dalmanitid occurrences. Modified from Cichowolski \& Rustán (2017).

from the Silurian of the United States. Additionally, the diagnosis of Synphoriinae does not consider the absence of a cephalic epiborder furrow or the number of pygidial axial rings (Holloway 1981), in order to classify taxa as Lygdozoon. In spite of this, such characters are still usually considered diagnostic of Dalmanitinae. In our case, we recognize a combination of character states of more than one subfamily in some new taxa proposed herein. Consequently, pending a complete phylogenetic analysis of Dalmanitidae in order to clarify their taxonomy, in the present contribution we do not propose subfamilial assignments for these new taxa. In discussions, for matter of ease, we refer to Dalmanitinae and Synphoriinae taking into account considerations given by Holloway (1981).

\section{Ivanites $\mathrm{n}$. gen.}

(Figs 3; 4)

urn:Isid:zoobank.org:act:05E3FE79-071D-4804-8373-F32E8FD7C6F6

TYPE AND ONLY SPECIES. - Ivanites leonorae n. sp.

Type Locality. - Quebrada de Talacasto, San Juan Province, Argentina.
Etymology. - Belonging to Ivan, for Ivan Grunewald, EAR's cousin.

OCCURRENCE. - Lochkovian-Pragian, lower part of the Talacasto Formation, Quebrada de las Aguaditas, Quebrada de Talacasto and Loma de los Piojos sections, San Juan Province, Argentina.

DiAgNosis. - Dalmanitid with a smooth, widely subparabolic, cephalic margin. Very narrow sag. and exsag. anterior border, with a shallow epiborder furrow. Absence of preglabellar field. Glabella piriform-shaped, nearly flat in the mid-posterior portion; with frontal lobe slightly inflated and less convex sagitally in lateral view, nearly oval to sub-rhombic and evenly convex anteriorly in dorsal view. S1-S2 nearly straight and transversal, without contacting the axial furrows, with the adaxial portion apodemal and incised. Apodems of S1 slightly convex forward, located nearly at the same exsagittal distance to SO and apodems of S2. Eye maximum length exsag. nearly $40 \%$ of maximum cranidium length sag. Ocular surface anteriorly taller, with approximately 45 vertical rows of no more than 16 lenses each. Pygidium without ornamentation, broadly subtriangular with 18-20 axial rings and 14 pleurae. Five to six anteriormost pleurae sinuous (more convex forward at level of fulcrum), then tending to be evenly curved backward. Anterior and posterior pygidial pleural bands of equal length exsag. Pygidial pleural furrows incised and symmetrical in cross-section exsag. Pygidial interpleural furrows incised, approximately parallel to pleural furrows. Pygidial border and distal part of pleurae steeply inclined downward. Post axial region ridge-like dorsally, as a stout mucro in posterior view. 


\section{REMARKS}

The material used to define Ivanites was doubtfully assigned to Kasachstania Maksimova, 1972 by Rustán (2016). Ivanites differs from Kasachstania, based on our recent emendation of its diagnosis (Randolfe et al. 2020), in having shorter exsag. eyes, S1 and S2 without contacting axial furrows, subtriangular pygidium (not heart-shaped), higher number of axial rings and pleurae, pleural bands and furrows parallel and more sinuous, pleural bands of equal width exsag., and pleural furrows symmetrical in cross-section.

Ivanites challenges the current classification of subfamilies because it possesses diagnostic characters of both Dalmanitinae and Synphoriinae. The lack of well-developed cephalic and pygidial borders, the location of eyes and the width of pygidial pleural bands resemble the synphoriinines but the spacing between glabellar apodems, the number of pygidial segments and the presence of an epiborder furrow are characteristic of dalmanitines. This particular combination of characters supports Ivanites as a new genus and encourages a taxonomic revision of dalmanitid subfamilies.

Ivanites leonorae n. gen., n. sp.

(Figs 3; 4)

urn:Isid:zoobank.org:act:4E9AE8A7-77D6-4E5D-B465-D4FB4EC303ED

Kasachstania? sp. Rustán, 2016: 137; fig. 6.

TYPE MATERIAL. - Holotype. One enrolled specimen CORD-PZ 7114; Fig. 3B, E, H, K, M-N; and Fig. 4A, D, E, G, from Quebrada de las Aguaditas (Lochkovian-Pragian).

Paratypes. Two cephala: CEGH-UNC 12736, from Quebrada de las Aguaditas (Lochkovian-Pragian); Fig. 3C, F, I, L, O-Q; and CEGH-UNC 24430 (assigned with doubt), from Quebrada de Talacasto (Pragian); Fig. 3A, D, G, J; and one pygidium: CEGHUNC 24424, from Loma de los Piojos (Lochkovian-Pragian); Fig. 4B, C, F, H.

Type Locality. - Quebrada de Talacasto, San Juan Province, Argentina.

ETYMOLOGY. - This taxon is dedicated to Irene Leonor Grunewald, EAR's mother.

OCCURRENCE. - As for the genus.

DiagnOSIS. - As for the genus (monospecific).

\section{DESCRIPTION}

Whole dorsal surface of carapace lacking ornamentation.

Cephalon widely parabolic in dorsal view. Cranidium with length/width index approximately 0.55 , with a minimum of convexity in the anterolateral sides. Very short sag. and exsag. preglabellar area, less than $0.1 \%$ of total cranidial length sag. Shallow epiborder furrow running close to margin, narrowest in the anterior portion.

Glabella expanding tr. rather evenly forward, maximum width tr. located in the middle part of the frontal lobe, nearly equivalent to 0.6 of maximum cephalic width tr.
Glabella piriform-shaped, with axial furrows nearly straight and weakly divergent forward (approx. $16^{\circ}$ ) in the posterior part up to the junction with S3, then strongly divergent (approx. $34^{\circ}$ ) up to the cephalic border, shallowest adjacent to the anterior part of the eye and deepest adjacent to S1. Shallow and delicately incised preglabellar furrow. Preglabellar field not developed.

SO nearly straight, barely sinuous laterally, very narrow sag., exsag. and shallow (Fig. 3H). S1 nearly straight, narrow sag., exsag., shallowing laterally to fade without contacting axial furrows, incised, becoming deeper, apodemal, adaxially. Apodems slightly convex forward, located nearly at the same exsagittal distance to SO and apodems of S2. S2 nearly straight, shorter tr. than $S 1$, shallowing and fading laterally without contacting axial furrows, apodemal adaxially. S3 anterolaterally oriented, narrowest exsag. adaxially then broadening anterolaterally, effaced adjacent to anterior part of the eye in the contact with axial furrows. LO insufficiently appreciable. L1 short exsag., subrectangular, scarcely inflated and corresponding to $10 \%$ of glabellar total length sag. L2 slightly larger sag. than L1, subrectangular and barely more inflated near the axial furrows. L3 larger exsag. than L2, rapidly expanded anterolaterally, slightly inflated near the axial furrows.

Glabellar frontal lobe dorsally oval to sub-rhombic, from slightly convex in posterior part to gently convex and sloping forwards anteriorly in lateral view, weakly inflated and convex dorsally with a slightly depressed median dorsal area subtly elongated exsag.; posteromedial impression subtly expressed.

Eye kidney-shaped in dorsal view, with posterior edge opposite of $\mathrm{S} 1$ and anterior edge opposite to contact between axial furrows and S3. Eye maximum length exsag. about $40 \%$ of cranidium total length sag., and maximum width tr. about $15 \%$ of cephalon total width tr., ocular surface taller in anterior part, gently convex and subvertical in general, more vertically oriented in the posterior part (Fig. 3E). Lenses regularly ordered in 45 vertical rows with a maximum of 16 lenses, with smaller ones in lower position. Lens formula, according the most complete eye from CORD-PZ 7114, is (from anterior): 2? 7? 9? 91112131314 14? 1515 ? 15161515151515151515141413121212 11111010998887666 6? 5? 4? 2? (Fig. 3M).

Palpebral furrow moderately deep and strongly convex exsag., deeper anteriorly, narrower tr. and shallower backward.

Shallow and broad exsag. subocular ridge. Anterior branch of facial suture running subparallel to axial furrows, then circumscribing the glabellar frontal lobe. Posterior branch of facial suture running with a strong convexity anterolaterally from the posterior part of the eye, turning backwards and reaching lateral margin a little behind of the half exsag. of eye. Palpebral area elevated in comparison with remaining fixigenal field, slightly convex dorsally in posterior view. Postocular area moderately inclined laterally and slightly convex. Posterior border furrow in appearance deep and narrow exsag. Librigenal field narrow tr., depressed and steeply sloped downwards. Lateral border furrow broader tr. and deeper on librigenal field than on fixigenal field. Anterior border furrow indistinguishable of preglabellar furrow. Genal spine (from specimen CEGH-UNC 24430, Fig. 3G), slightly shorter than the cranidium total length sag., as wide as $10 \%$ of cephalon maximum width tr. Posterior border 


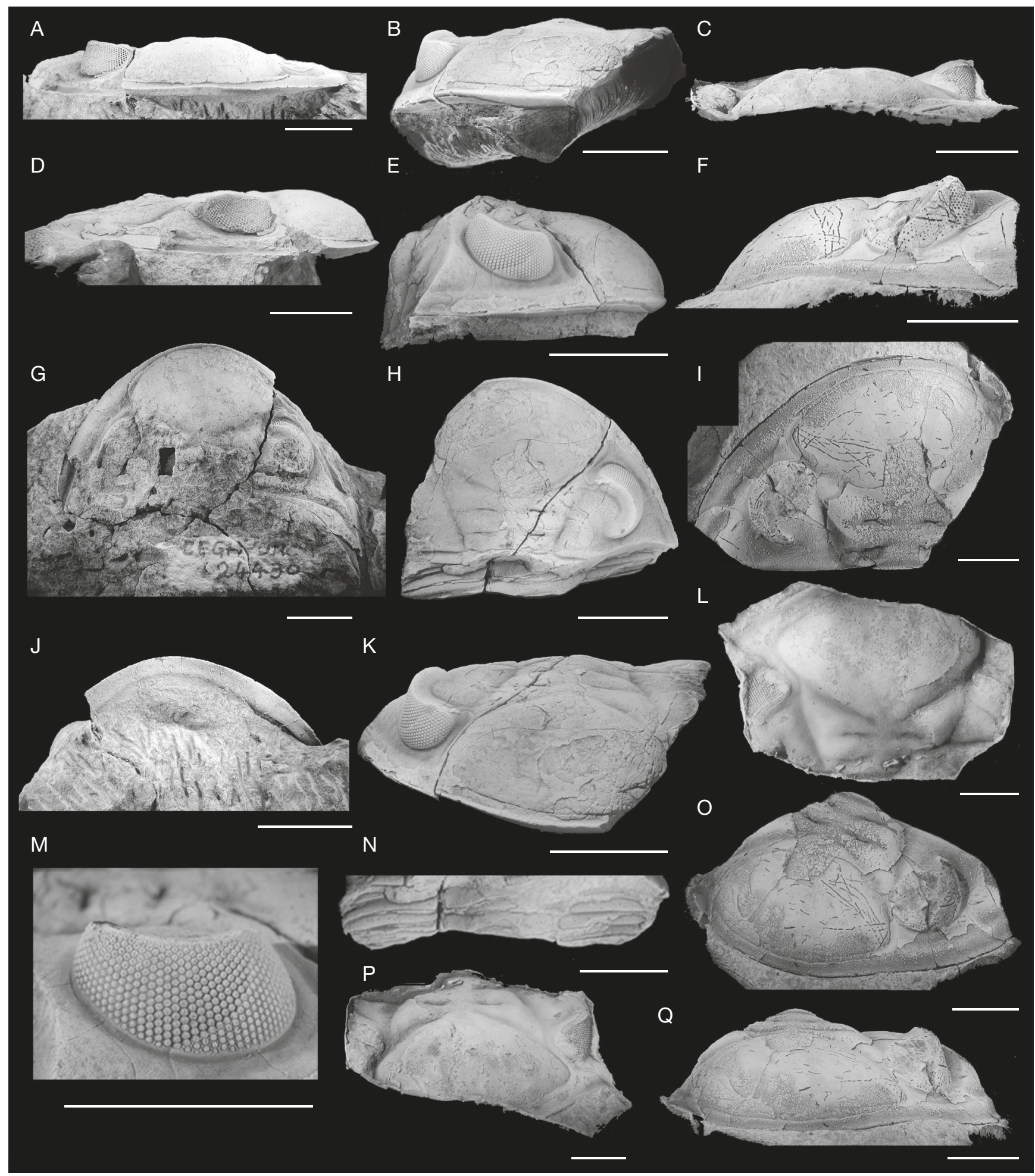

FIG. 3. - Ivanites leonorae n. gen., n. sp., cephala from the Lochkovian-Pragian of Talacasto Formation, Precordillera Argentina: A, D, G, J, CEGH-UNC 24430, internal mold of cephalon assigned with doubt, from Quebrada de Talacasto: A, frontal view; D, lateral view; G, dorsal view; J, ventral view; B, E, H, K, M, N CORD-PZ 7114, holotype, enrolled specimen, from Quebrada de las Aguaditas: B, frontal view; E, lateral view; H, dorsal view; K, dorsofrontal view; M, eye; N, dorsal view of thoracic segments; C, F, I, L, O-Q, CEGH-UNC 12736, cephalon from Quebrada de las Aguaditas: F, internal mould lateral view; I, idem dorsal view; $\mathbf{O}$, idem dorsolateral view; $\mathbf{Q}$, idem dorsofrontal view; C, latex mould, frontal view; $\mathbf{L}$, idem dorsal view; $\mathbf{P}$, idem dorsofrontal view. Scale bars: $1.0 \mathrm{~cm}$

furrow continued into the base of the genal spine. Anterior cephalic doublure (according specimen CEGH-UNC 24430, Fig. 3J), with length sag. about $15 \%$ of total cranidium length sag., nearly flat to barely concave with a very shallow furrow near margin. More depressed internal area about $50 \%$ of total doublure length sag., posteriorly located. 
Hypostome unknown.

Thorax scarcely known (Fig. 3N). Axis with 37\% of thorax total width tr. across the most anterior segments. Median part sag. of axial rings convex anteriorly and concave posteriorly in dorsal view, lateral sides slightly convex. Axial rings more convex medially in transversal view.

Pygidium broadly subtriangular in dorsal view, with length/ width index approximately 0.8 . Axial furrows nearly straight to barely convex laterally, very narrow tr. and moderately deep, diverging from sagittal plane about $6-7^{\circ}$. Pygidial axis narrow, approximately $25 \%$ of the maximum pygidial width tr., with a maximum of dorsal convexity tr. medially and just a barely concave profile in lateral view, with 18-20 well-defined axial rings plus a terminal piece. First pygidial eight axial rings gently elevated dorsally in the posterior part, in lateral view, then becoming nearly flat and effaced backward. Nearly first seven axial rings with convex to sub-rectangular lateral sides in dorsal view, posterior ones nearly sub-rectangular. Interring furrows narrow sag., deepest laterally, effaced medially sag. Inter-ring furrows effaced sagittally in the posterior part of the axis, defining a median band of even width tr. Pleural field with 14 pleurae, narrow exsag. and deep pleural furrows, gradually less impressed backward and more posteriorly directed. Anteriormost pleurae (particularly the first seven) sinuous (slightly convex backward near axial furrow, then strongly convex forward toward fulcrum) bending backwards at fulcrum. Posteriormost pleurae becoming progressively straighter and backwardly oriented, trending to be parallel to the axis. Interpleural furrows well-impressed, incised, and symmetrical in cross-section exsag. Pleural bands and furrows progressively fading distally to efface next to pygidial margin, leaving an insinuated pygidial border. Pygidial border and distal part of pleurae steeply inclined downward. Stout caudal mucro slightly downward directed with acute dorsal convexity, tip not adequately preserved.

\section{REMARKS}

Ivanites leonorae n. gen., n. sp. resembles "Kasachstania" gerardoi Edgecombe \& Ramsköld, 1994, a species with current uncertain generic assignment (Randolfe et al. 2020), from the upper Silurian of Bolivia and Lower Devonian of Argentina. Ivanites leonorae n. gen., n. sp. differs in having smaller exsag. eyes, anteriorly evenly rounded glabellar frontal lobe in dorsal view (not acute), a less rounded pygidium, much narrower exsag. pygidial pleural furrows, distal part of pleural bands without elevations and depressions, delicately convex pygidial border instead of being wide tr. and concave, and distal part more depressed toward the mucro.

The cephalon CEGH-UNC 24430 (Fig. 3A, D, G, J) is assigned with doubt to I. leonorae n. gen., n. sp. Differences with other cephala of $I$. leonorae n. gen., n. sp. include a lower profile in lateral view, margin nearly straight in lateral and frontal view, lower eyes in appearance with less rows of lenses and frontal lobe not so convex and steeply inclined forward anteriorly. This specimen originated from sandy layers (Pragian of the Quebrada de Talacasto section), in contrast with remaining specimens of $I$. leonorae n. gen., n. sp. coming from nodules from the pelitic lowermost part of the Talacasto Formation (Lochkovian to Pragian from Quebrada de las Aguaditas and Loma de los Piojos sections), and thus some morphological differences might be, taphonomic, due to a slight dorso-ventral compression. This specimen is the only one preserving a genal spine and consequently its characters were not included in the diagnosis. Such genal spines, exhibiting the posterior border furrow continued in a longitudinal genal furrow, were considered typical of Dalmanitinae (Campbell 1977).

\section{Aguaditaspis n. gen.}

(Figs 5; 6)

urn:Isid:zoobank.org:act:3F3AFB54-4B5D-44BD-BE22-592CD7BF5DFE

TyPe SPECIES. - Aguaditaspis mediaspina n. sp.

Type Locality. - Quebrada de Talacasto, San Juan Province, Argentina.

ETyMology. - From Quebrada de las Aguaditas, the type locality in San Juan Province to the southwest of Jáchal city (Argentina), and the Greek end meaning shield, as usual in trilobites.

OCCURRENCE. - Lochkovian-Pragian, lower muddy part of the Talacasto Formation, Quebrada de las Aguaditas, San Juan Province and Sierra de las Minitas, La Rioja Province, Argentina.

Diagnosis. - Dalmanitid with strongly impressed glabellar furrows, nearly contacting axial furrows. S1 and S2, posterolaterally directed, with short tr. and deep apodems adaxially, with convex projections of glabellar lobes protruding them from behind. S1 slightly concave forward. S2 nearly straight. L1 elongated tr., L2 subrectangular and L3 subtriangular (broadest abaxially and acute adaxially). Tall palpebral area with very shallow and broad exsag. palpebral furrow anteriorly. Eye socle furrow deep and broader exsag. Robust subocular ridge. Anterior branch of facial suture cuts subocular ridge, dividing space between subocular ridge and eye socle furrow in a librigenal and a cranidial portion. Wide tr., exsag. postocular area. Lateral border furrow broad tr. anteriorly, fading posteriorly without contacting posterior border furrow. Very shallow epiborder furrow. Deep and wide exsag. posterior border furrow. Pygidium subtriangular with 18-24 axial rings, most anterior ones usually bearing postero-sagital spines dorsally or inflations variably developed. Well-defined pygidial pleurae, anterior ones evenly wide exsag., five posterior ones progressively straighter, broader tr. and effaced distally. Pygidial interpleural furrows weakly impressed. Pleural furrows broad and deep, with anterior slope steeper than posterior one, posteriormost five somewhat sinuous and variably in width and depth each.

\section{REMARKS}

This genus is based on a new combination of characters and some derived characters. Particularly distribution, orientation, width and depth of cephalic furrows are unique. A convex projection of cephalic lobes forward into the glabellar apodems, as reported in detail on the S2 of Dalmanitoides, from the Lower Devonian of Southwestern Gondwanan basins (Rustán \& Vaccari 2012), is a character often overlooked in dalmanitid descriptions. In Aguaditaspis n. gen., a similar 


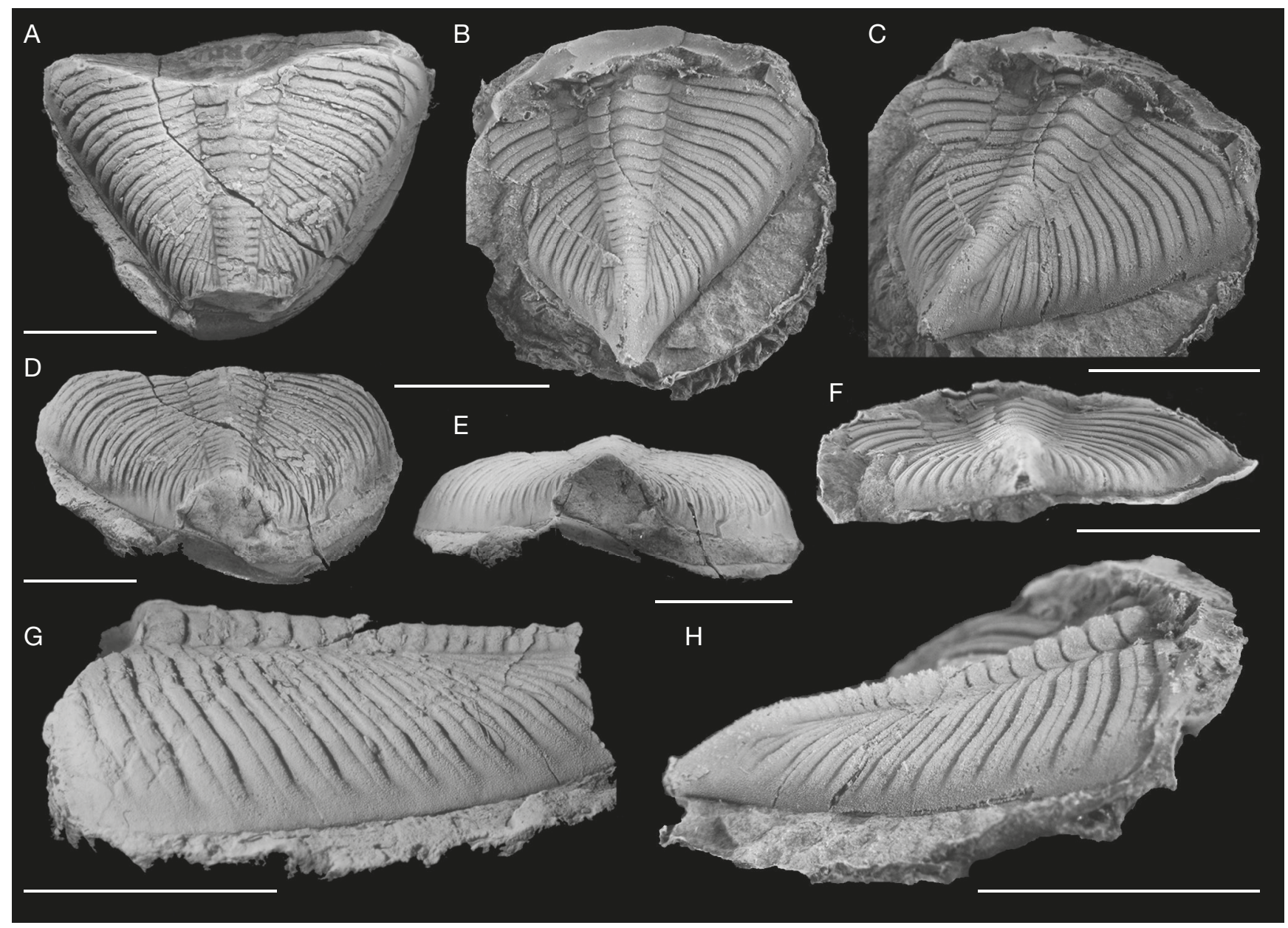

FIG. 4. - Ivanites leonorae n. gen., n. sp., pygidia from the Lochkovian-Pragian of Talacasto Formation, Precordillera Argentina: A, D, E, G, CORD-PZ 7114, holotype, enrolled specimen from Quebrada de las Aguaditas: A, dorsal view; D, dorsoposterior view; E, posterior view; G, lateral view; B, C, F, H, CEGH-UNC 24424, pygidium from Loma de los Piojos, latex mould: B, dorsal view; C, dorsolateral view; F, posterior view; H, lateral view. Scale bars: $1.0 \mathrm{~cm}$.

convex projection is particularly clear on $\mathrm{S} 1$. However, the only known cephalon is an internal mold (CEGH-UNC 27418, Fig. 5A, B), so that some features of these external characters might be slightly different than described herein. A subocular ridge is a character also overlooked in many dalmanitid descriptions. However, in Aguaditaspis n. gen. the facial suture cuts this robust subocular ridge, in a particular and rare case (Fig. 5A). Median spines or inflations variably developed in several pygidial axial rings is a character extremely unusual in dalmanitids. This derived character may also include single median spines on thoracic axial rings or even in the occipital ring, but the available material is insufficiently preserved to asses this (Fig. 5E, F, L). The area corresponding to the five posteriormost pleurae in the pygidium is distinctive in terms of its expression, orientation, course, width and depth of furrows. The furrows are not strictly sinuous but somewhat irregular, even in internal molds (Fig. 5E, F, M, N).

Aguaditaspis n. gen. shares characters of both subfamilies, Synphoriinae and Dalmanitinae (Holloway 1981), challenging their taxonomic recognition. Particularly, a cephalic epiborder furrow, a pygidium with more than twelve axial rings and a steeply inclined anterior slope of pleural furrows, are related to Dalmanitinae. In turn, a weakly defined cephalic and pygidial border, and the sagittal distance between $\mathrm{S} 1$ and S2 apodems 1.5 times than distance between S1 and SO apodems, belong to Synphoriinae diagnosis. The shape of the hypostome of Aguaditaspis $\mathrm{n}$. gen. is similar to some synphoriinines as Lygdozoon, but having a very shallower maculae.

Aguaditaspis mediaspina n. gen., n. sp. (Figs 5; 6)

urn:Isid:zoobank.org:act:53FB3DCF-9ECD-4B37-9664-F24CA0CF9FDA

Type MATerial. - Holotype. 1 enrolled specimen CEGHUNC 27418; Fig. 5A-D, G, from Quebrada de las Aguaditas (Lochkovian-Pragian).

Paratypes. 4 pygidia: CEGH-UNC 27419, from Quebrada de las Aguaditas (Lochkovian-Pragian); Fig. 5E, F, H, I, K, L; CEGHUNC 12735, from Quebrada de las Aguaditas (LochkovianPragian); Fig. 5N, Q; PULR-I 006, from Sierra de las Minitas (Lochkovian-Pragian); Fig. 5J, M, P; PULR 132, from Sierra de las Minitas (Lochkovian-Pragian); Fig. $5 \mathrm{O}$. 
Type Locality. - Quebrada de Talacasto, San Juan Province, Argentina.

Eтyмоlogy. - From Latin. Refers the presence of one dorsal median spine in some pygidial axial rings.

OCCURRENCE. - As for the genus.

Diagnosis. - As for the genus (monospecific).

\section{DESCRIPTION}

Cephalon approximately subparabolic in dorsal view. Shallow epiborder furrow running close to the margin.

Glabella expanding tr. rather evenly forward in dorsal view, maximum width tr. located in frontal lobe, equivalent to half of maximum cephalic width tr. Posterior part of glabella sloping slightly forward up to S3, in lateral view. Glabellar frontal lobe incompletely known but with a barely depressed or gently convex medial dorsal area in the posterior part, in lateral view.

Glabellar axial furrows, nearly straight and weakly divergent (approx. $16^{\circ}$ ) forward up to junction with S3, where describe a local outward convexity, and then slightly more divergent (approx. $25^{\circ}$ ), shallowest adjacent to the anterior part of the eye and deepest adjacent to S1. SO slightly convex anteriorly in medial part where is shallowest, and concave forward laterally becoming apodemal. S1 nearly posterolaterally directed, broader exsag. abaxially, shallowest at junction with axial furrows, more adaxially with a short tr. apodemal pit with a little convex intrusion of the L1. S2 nearly straight and barely posterolaterally directed, shallowest at junction with axial furrows, apodemal adaxially with a little convex intrusion of the L2. S3 anterolaterally directed, effaced sagitally, narrow adaxially then broadening and deepening anterolaterally nearly at junction with axial furrows. LO not well-preserved but long sag.; exsag., longer sagitally, slightly convex anteromedially, lateral sides nearly concave forward in dorsal view. L1 short exsag., subrectangular to elongated, laterally acuminated, scarcely inflated, higher than L2 in lateral view. L2 approximately twice longer (sag.; exsag) than L1, subrectangular, inflated. L3 subtriangular, expanded anterolaterally, barely longer exsag. than L1 abaxially, inflated, protruding slightly anterolaterally.

Eye kidney-shaped in dorsal view, with posterior edge opposite to posterior part of L2 and anterior edge opposite to contact between axial furrows and S3. Eye maximum width tr. about $10 \%$ of cephalon total width tr., ocular surface taller in anterior part, gently convex and steeply inclined in general, more vertical in posterior part. Complete lens formula unknown. Lenses regularly ordered in approximately 48 vertical rows with not more than 4-18 lenses each.

Palpebral furrow shallow and slightly convex laterally, broader tr. anteriorly.

Anterior branch of facial suture running subparallel to and near external sides of axial furrows from the anterior part of eye, cuts subocular ridge (Fig. 5A), then circumscribing exteriorly the anterolateral corner of the glabellar frontal lobe. Posterior branch of facial running anterolaterally from behind the eye along the posterior part of the eye socle furrow, then strongly and evenly convex forward across the lateral border furrow opposite to S2, and turning backwards to the margin across the border opposite to L2. Subocular ridge robust and extended anteriorly almost reaching axial furrows. Eye socle furrow shallow, broadest tr. anteriorly. Palpebral area elevated, slightly convex dorsally in posterior view. Postocular area moderately inclined towards lateral border, gently convex in lateral view. Posterior border furrow wide exsag. and deep, shallowest and narrower exsag. adaxially. Librigenal very narrow tr., steeply sloped downward to lateral border furrow.

Anterior cephalic doublure ventrally convex (Fig. 5B).

Hypostome big (of about $28 \mathrm{~mm}$ sagittal length), with a shield-like shape resembling an inverted bell, slightly wider than longer (length/width index, 0.9), convex ventrally; with anterior margin evenly convex forward; conspicuous anterior wings, lateral side concave anteriorly and evenly convex posteriorly, posterior margin incompletely known but convex with at least one posterolateral denticle. Separation between anterior border and middle body without any furrow. Middle body more elevated medially than anterior border, convex in lateral view. Middle furrow and macula only slightly expressed. Lateral border furrow shallow and narrow. Posterior border furrow broader sag. and deeper than lateral border furrow. Posterior body not completely known, subtriangular in ventral view and lower than middle body in lateral view (Fig. 5C).

Thorax known from a few incomplete segments (Fig. 5A, D-F, L). Axis about 25-30\% of thoracic width tr. Axial furrows well-impressed. Axial rings subrectangular in dorsal view, strongly convex medially in transversal view; with a discrete dorsal inflation in the anterolateral corner (Fig. 5D). Pleural tips unknown, pleural furrows deep, broad exsag., and asymmetrical in cross section, the anterior slope more steeply inclined, shallowest and narrowest at junction with axial furrows. Anterior pleural band narrower exsag. than posterior pleural band. Short and stout dorsal spine posteromedially located in at least some posterior thoracic segments (Fig. 5E, F, L).

Subtriangular pygidium, with length/width index of nearly 1.0, based on an estimated total length sag. Axial furrows nearly straight, narrow tr. and shallow, with a low divergence from the sagittal line (about $6^{\circ}$ ). Pygidial axis approximately $30 \%$ maximum pygidial width tr., measured at the first axial ring. As much as 18-20 well-defined pygidial axial rings plus a terminal piece. First six pygidial axial rings slightly convex forward anteriorly and concave backward posteriorly, adaxially, in dorsal view; with lateral sides somewhat broader and barely inflated; posteriormost ones more subrectangular in dorsal view. Each axial ring gently inclined forward dorsally and more convex and higher posteriorly in lateral view, with a short posteromedial spine or inflation variably developed typically in anteriormost 12 axial rings. Inter-ring furrows narrow (sag., exsag) but well-impressed, becoming apodemal abaxially. Apodemal pits without contacting axial furrows. Pleural field with at least 13 pleurae gently inclined forward in lateral view, bearing broad exsag. and deep pleural furrows. Anteriormost pleurae (particularly the first five) somewhat sinuous (slightly convex backward near axial furrow, then strongly bending backward at fulcrum). Posteriormost pleurae progressively becoming nearly straight and backwardly oriented, trending to be parallel to the axis, straighter and more 

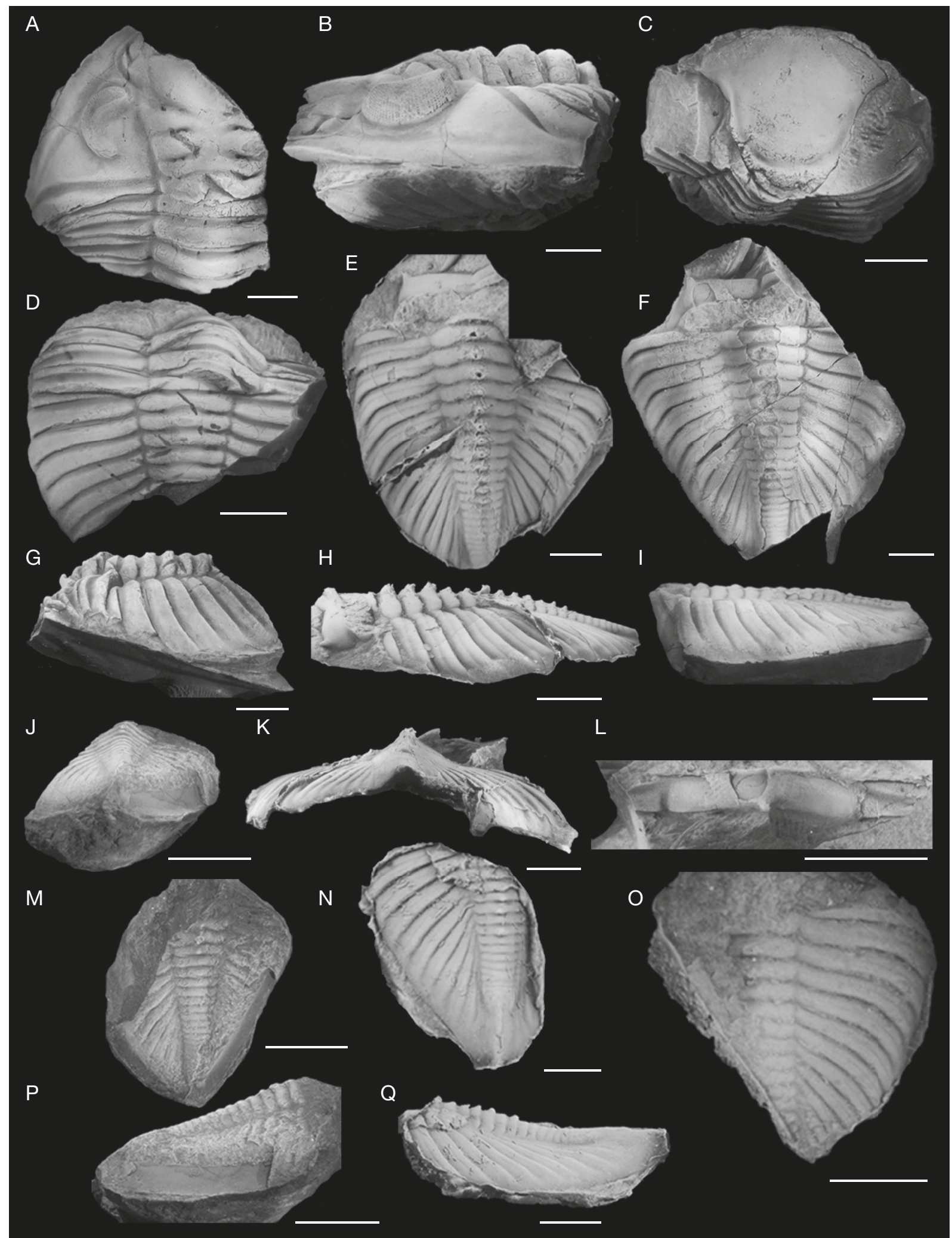

FIG. 5. - Aguaditaspis mediaspina n. gen., n. sp., from the Lochkovian-Pragian of Talacasto Formation, Precordillera Argentina: A-D, G, CEGH-UNC 27418, holotype, internal mould of enrolled specimen, from Quebrada de las Aguaditas: A, dorsal view of cephalon and some thoracic segments; B, lateral view of cephalon; C, dorsal view of hypostome; D, dorsal view of pygidium; G, lateral view of pygidium; E, F, H, I, K, L, CEGH-UNC 27419, pygidium from Quebrada de las Aguaditas: F, internal mould dorsal view; I, idem lateral view; L, idem detail of thoracic segment; $\mathbf{E}$, latex mould dorsal view; H, idem lateral view; K, idem posterior view; J, M, P, PULR-I 006, internal mould of pygidium from Sierra de las Minitas: J, posterior view; M, dorsal view; P, lateral view; N, Q, latex mould of pygidium CEGH-UNC 12735 from Quebrada de las Aguaditas: N, dorsal view; Q, lateral view; O, latex mould of pygidium PULR 132 from Sierra de las Minitas, dorsal view. Scale bars: $1.0 \mathrm{~cm}$. 
posterolaterally directed. Interpleural furrows shallow, sinuous as pleural bands, barely impressed in internal molds. Anterior pleural bands broader exsag. and extended more distally than posterior band. Anterior pleural bands broader exsag. near pygidial margin. Pleural furrows asymmetrical with anterior slope steeper than posterior one. Pleural bands and furrows become progressively faint distally to efface next to pygidial margin, leaving an insinuated pygidial border. Short pygidial doublure, slightly convex ventrally (Fig. 5J, M, P). Postaxial region wide tr. and elongated, with a gently dorsal postaxial keel-like ridge (Fig. $5 \mathrm{~N}$ ), but unknown in the very rear part from the available material, in appearance, tapering in widebased and stout mucro or spine.

\section{REMARKS}

Pygidial interpleural furrows of Aguaditaspis mediaspina n. gen., n. sp. are extremely shallow in external molds (Fig. 5E), and barely impressed in internal molds (Fig. 5D, F). Thus, the apparent absence of interpleural furrows is a doubtful character to use when external information of the carapace is not available.

The distribution pattern of dorsal median spinosity on axial rings of the pygidium, and the expression of the spines, varies among specimens. We interpret it as intraspecific variability, as was recognized in other dalmanitids (Rustán \& Vaccari 2012) such as Dalmanitoides drevermanni (Delo, 1935).

External morphology of the thoracic axial rings of $A$. mediaspina n. gen., n. sp. is known from a single segment derived from the specimen CEGH-UNC 27419 (Fig. 5E, F, L), which exhibits a dorsal postero-sagittal spine. However, as spines expression seems to be variable, we did not include spines of thoracic axial rings as a diagnostic character.

\section{Aguaditaspis mediaspina?}

MATERIAL. - Two incomplete pygidia from Quebrada de las Aguaditas (CEGH-UNC 27421; Fig. 6A, B, D, E, I, J; and CEGH-UNC 27420; Fig. 6C, F-H).

Occurrence. - Lochkovian-Pragian, Talacasto Formation, Quebrada de las Aguaditas, San Juan, Precordillera Argentina, Argentina.

\section{DESCRIPTION}

Because of their tentative assignment, description of these specimens is herein focused on characters differing from others $A$. mediaspina n. gen., n. sp.

Axial furrows broad tr., moderately deep, with a weak divergence from sagittal line $\left(7^{\circ}\right)$. Axis with at least 24 axial rings. Axial terminus poorly defined. Anterior 13 rings strongly defined, lateral sides convex in dorsal view. Anterior side of first 13 rings convex and posterior side slightly concave. First four axial rings bearing dorsal posteromedial nodes. Pleural field with 15 pleurae, bearing pleural furrows, gradually less impressed backward and more posteriorly directed. Anteriormost pleural furrows (particularly the first six) slightly convex adaxially, interpleural furrows nearly straight. Interpleural furrows slightly impressed in first six pleurae, then even less impressed, and symmetrical in cross-section. Posterior pleural bands narrower exsag. and more vaulted than anterior pleural bands. Pygidial caudal border with a little sag. and relatively broad tr. spine with a rounded base ventrally directed. Regular granular ornamentation in posterior region of axial rings and anterior pleural bands, also present in surface of terminal piece but less densely distributed.

\section{REMARKS}

A number of pygidia assigned herein with doubt to $A$. mediaspina n. gen., n. sp., co-occur in the same layers of the Quebrada de las Aguaditas type locality, and are very similar to those of $A$. mediaspina n. gen., n. sp. They share some diagnostic characters: a steeply inclined anterior slope of pleural furrows; ornamentation posteromedially located on some axial rings, similar sinuosity of pleural bands and furrows and an elongated and stout post-axial region. Differences include, in these specimens, wider pleural bands exsag., interpleural furrows better impressed, higher number of axial rings, an extremely subdued post-axial ridge, and ornamentation of axial rings compound of medial nodes or subtle inflations instead of spines. Furthermore, the number of axial rings is remarkably high for most dalmanitids (more than 20 is extremely rare) and the anterior slope of pleural furrows is typically much steeper than the posterior slope. However, the general pygidial morphology is consistent, and no similar taxa are known outside from the fossiliferous interval of the Quebrada de las Aguaditas. Hence, we interpret that differences among specimens might be due to intraspecific variability and refer putatively the specimens to $A$. mediaspina n. gen., n. sp.

A caudal spine, relatively short, stout, subtriangular in cross-section and ventrally directed distally is a unique character within dalmanitids. However, this character cannot be appreciated in $A$. mediaspina n. gen., n. sp., which caudal part is unknown in type specimens. Thus, the downturned caudal spine could not be used to solve the taxonomic proposal, nor was included in the diagnosis.

\section{New genus and species of Dalmanitidae} (Fig. 7)

Material. - One incomplete pygidium from Quebrada de las Aguaditas CEGH-UNC 27422; Fig. 7.

Occurrence. - Lochkovian-Pragian, Talacasto Formation, Quebrada de las Aguaditas, San Juan Province, Argentina.

\section{DESCRIPTION}

Pygidium subtriangular in dorsal view, with length/width index approximately 1.1. Axial furrows nearly straight, narrow tr., moderately deep, with a weak divergence from sagittal line (about $7^{\circ}$ ) along the first 15 axial rings, and then nearly parallel to the sagittal line, after a subdued constriction of the axis. Axis with 24 axial rings plus a terminal piece, slightly concave in lateral view. First axial ring approximately 30\% of the maximum pygidial width tr. Axial rings narrow sag., exsag. almost rectangular with slightly convex lateral sides in dorsal view. First 14 axial rings bearing typically two strong 


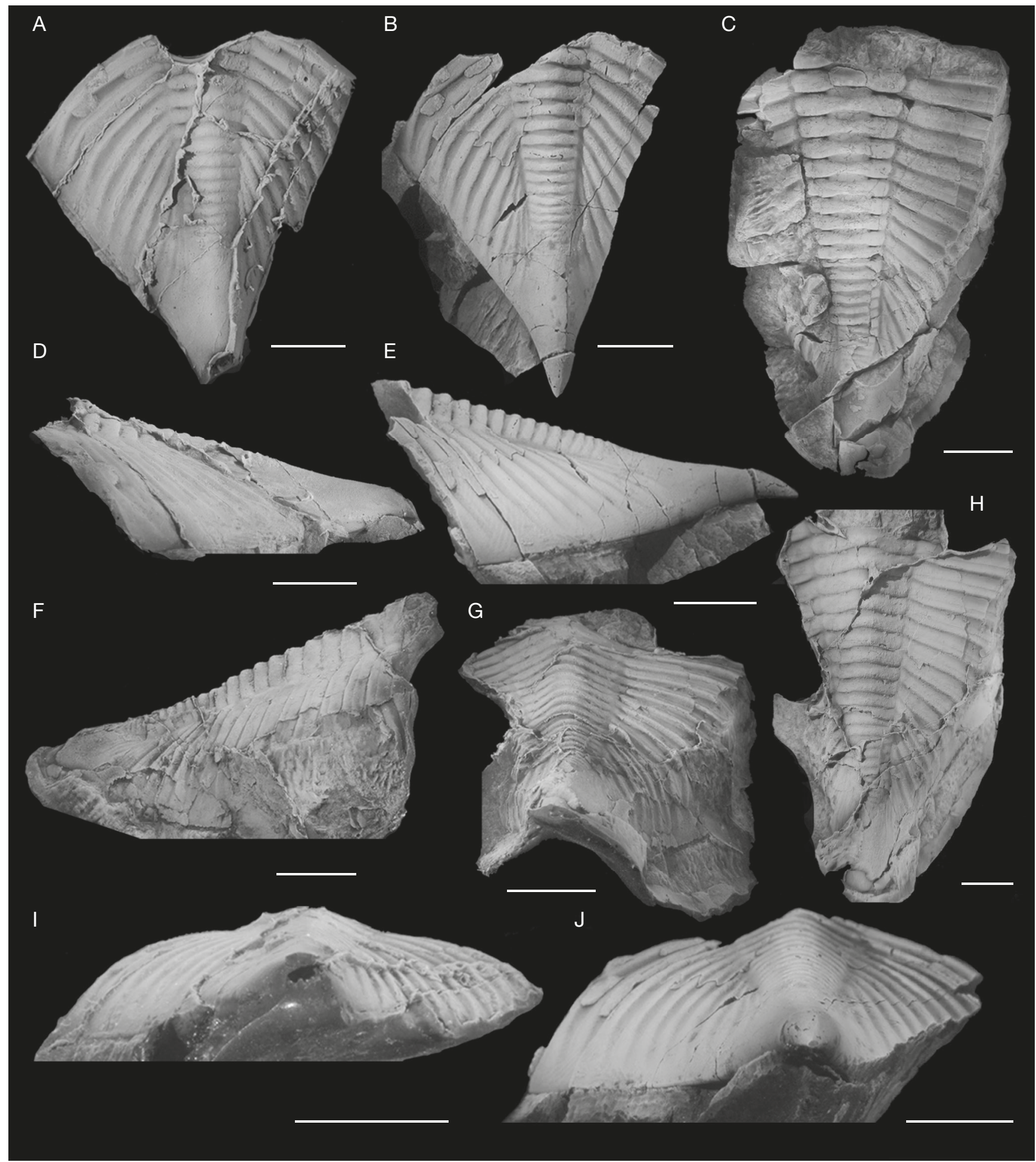

FIG. 6. - Aguaditaspis mediaspina?, pygidia from the Lochkovian-Pragian of Quebrada de las Aguaditas, Talacasto Formation, Precordillera Argentina: A, B, D, E, I, J, CEGH-UNC 27421: A, latex mould dorsal view; B, internal mould dorsal view; D, latex mould lateral view; E, internal mould lateral view; I, latex mould posterior view; J, internal mould posterior view; C, F-H, CEGH-UNC 27420: C, internal mould dorsal view; F, latex mould lateral view; G, idem dorsoposterior view; $\mathbf{H}$, idem dorsal view. Scale bars: $1.0 \mathrm{~cm}$.

adaxial dorsal small spines or spine-like tubercles, variably developed and arranged in two longitudinal rows (each on different sides of the sagittal plane), and usually two or more additional much smaller spines either laterally (in rings 1 to 5) or between them (in rings 1-2?; 5-11). Inter-ring furrows well-impressed, apodemal abaxially. Apodemal pits without contacting axial furrows. Pleural field with 16 pleurae, bearing broad exsag. and deep pleural furrows, gradually less impressed backward and more posterolaterally directed. Anteriormost pleurae (particularly the first nine) nearly straight to slightly 
concave forward in the pleural field adaxially from fulcrum, slightly convex backward toward the fulcrum, then bending strongly backward abaxially at fulcrum, distinguishable up to near the margin. Posteriormost pleurae progressively becoming nearly straight and backwardly oriented, trending to be parallel to the axis. Interpleural furrows well-impressed but incised and shallow. Anterior pleural bands convex dorsally in cross-section, higher, slightly broader exsag., and extending more distally than the posterior bands, becoming broadest exsag. near fulcrum. Anterior band of first six pleurae bearing typically 3-4 spine-like small tubercles irregularly and asymmetrically distributed. Posterior pleural band of the first two pleurae with little spines abaxially near fulcrum. Pleural bands and furrows becoming progressively faint distally to efface next to the pygidial margin, leaving a barely defined pygidial border. Caudal region elongated backward, with no ornamentation. Pygidial terminus continued in a gently upturned caudal spine of unknown total length. Regular granular ornamentation.

\section{REMARKS}

The new genus and species of Dalmanitidae combines diagnostic characters of Dalmanitinae, such as asymmetrical width exsag. of pygidial pleural bands, with characters of Synphoriinae as a poorly defined pygidial border and apodemal pits of pygidial axis without contacting axial furrows.

Ornamentation appears to be similar to that of Roncellia Lespérance \& Bourque, 1971, from the Lower Devonian of Canada; Fenestraspis, from the Lower Devonian of Bolivia; and especially Dalmanitoides. These genera share a very narrow tr. pygidial border, and spines/tubercles on several axial rings, usually paired and trending to define longitudinal rows. However, specimens of Dalmanitoides and Roncellia differ from our specimen by spines developed on the posterior pleural bands, instead of being located on the anterior ones. In turn, the broad bases of spines in Dalmanitoides protrude into the following anterior pleural band, which contrasts with the delicate spine bases of the new genus and species of Dalmanitidae. Our specimen could be differentiated from Dalmanitoides and Roncellia from its narrower tr. pygidium, a higher number of axial rings and pleurae, a straighter lateral margin, and absence of dorsal ornamentation on the last axial rings. Fenestraspis, in contrast, is clearly different by its unique intersegmental fenestrae and nearly straight pleurae. Hence, similarities in the ornamentation pattern among these genera are most probably due to evolutionary convergence, although this must be tested in a phylogenetic analysis.

The combination of the spines distribution pattern, the high number of axial rings and the sharp subtriangular shape with weakly convex lateral margins, is unique for a dalmanitid and suggest that this specimen corresponds to a new genus. We leave it in open nomenclature due to the scarcity of material.

It is worth mentioning an irregularity in the last three pleurae on the left side specimen (Fig. 7I). These pleurae appear to be fused adaxially, suggesting a malformation or a postdamage regeneration. It is closely similar to interpretations of post predation-marks (Šnajdr 1981). These abnormalities are explained as evidence of regeneration after failed predation, in which the margin regenerates first while successive moults change the pre-damage distribution of pleural furrows and bands. The typical result of this process would be a pygidial margin without any damage but pleural furrows and bands irregularly distributed, as in our case. However, it is very difficult to objectively distinguish post-damage regeneration from some teratological conditions (Owen 1985). Bicknell et al. (2019) proposed to reject a teratological origin for distinctive shapes of marginal embayments, marks of cicatrization and/or single spine injuries. Nevertheless, none of these characteristics have been seen in our specimen. In a study about abnormalities and spinosity in Cambrian trilobites, a correlation was found between development of spines and abundance of abnormalities (Pates \& Bicknell 2019). The conclusion of that publication was that in such cases abnormalities would correspond to post-predation marks. In either case, this is the first abnormality of this kind registered in post-Ordovician dalmanitids.

On the other hand, this specimen exhibits two little circular marks also located in the left pleural field, which look like sessile epibiont attachment structures (Fig. 7H). We interpret that these structures were probably post mortem and not related to predation.

\section{DISCUSSION}

\section{THE DALMANITID TRILOBITES IN THE CONTEXT} OF THE MALVINOKAFFric REALM

Trilobite faunas from the Early Devonian of Southwestern Gondwana were characterized as noticeably endemic already since their first reports (Clarke 1913; Richter \& Richter 1942), which allowed to recognize a major Early-Middle Devonian paleobiogeographical region of cold waters in high paleolatitudes (Dowding \& Ebach 2018). This region, known as the Malvinokaffric Realm, embraced relatively isolated tectonic basins and was considered a natural laboratory for analyzing evolutionary and paleobiogeographical patterns and processes in trilobites (Lieberman et al. 1991; Lieberman 1993). The earliest hypothesis to explain the extraordinary morphological disparity in Malvinokaffric trilobites proposed regional diversifications from previous Silurian cosmopolitan stocks (Eldredge \& Ormiston 1979). The bulk of studies focused on the calmoniids, an extremely diversified family occurring in the late Silurian-Middle Devonian, virtually endemic from Malvinokaffric basins (Eldredge \& Braniša 1980; Abe \& Lieberman 2009, 2012). However, other families include some wide-distributed representatives as is the case of phacopiids (Holloway \& Rustán 2012; Rustán \& Balseiro 2016). Dalmanitids in particular, were considered remarkably diversified and endemic of the Malvinokaffric basins, similarly to calmoniids (Eldredge \& Ormiston 1979). Thus, Kasachstania, previously reported from the upper Silurian-Middle Devonian of Kazakhstan, United States, Bolivia and Argentina was recently excluded from the Malvinokaffric Realm and interpreted as restricted 


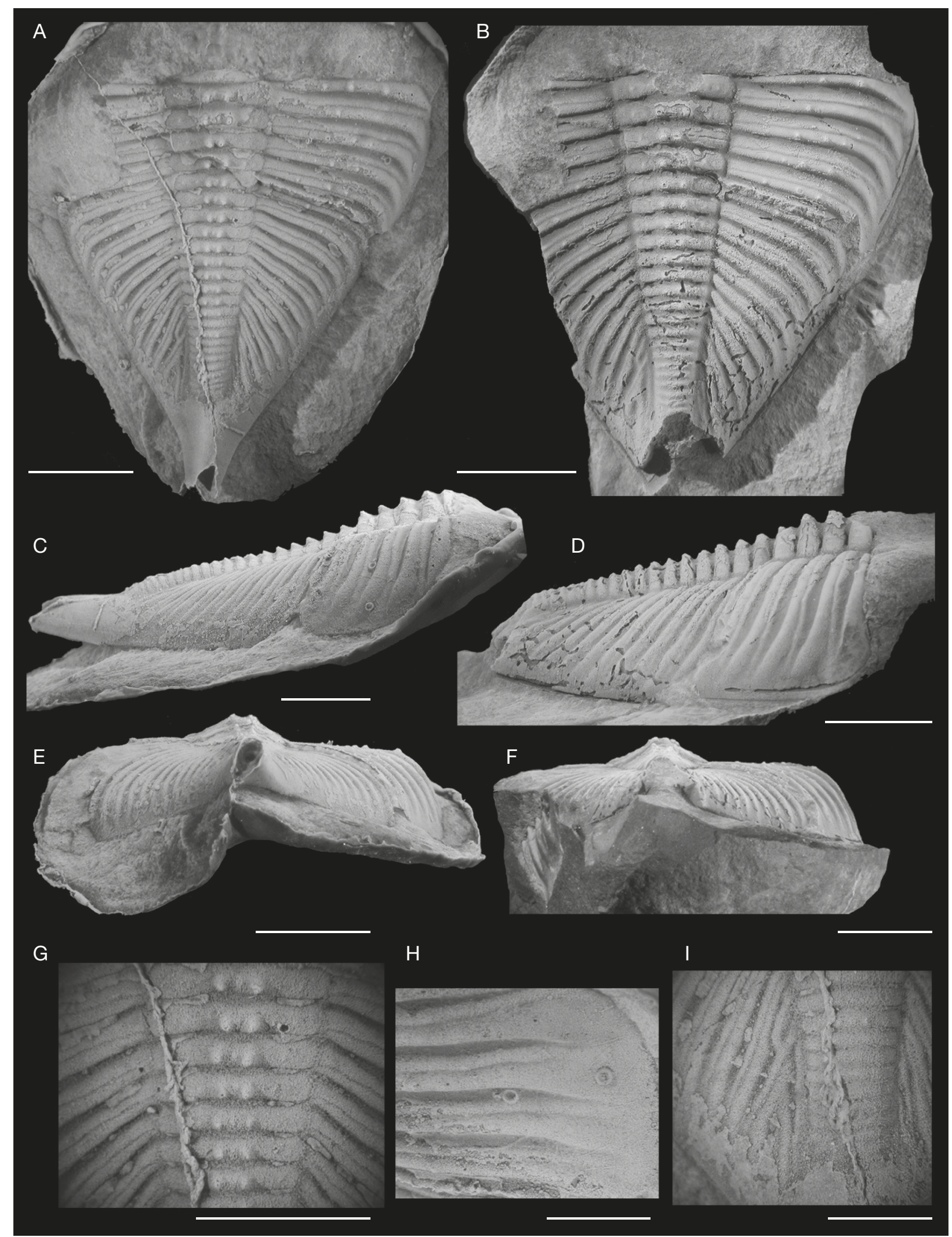

FIG. 7. - New genus and species of Dalmanitidae, pygidium from the Lochkovian-Pragian of Quebrada de las Aguaditas, Talacasto Formation, Precordillera Argentina. CEGH-UNC 27422: A, latex mould dorsal view; B, internal mould dorsal view; C, latex mould lateral view; D, internal mode lateral view; E, latex mould posterior view; $\mathbf{F}$, internal mould posterior view; $\mathbf{G}$, latex mould detail of axis; $\mathbf{H}$, idem detail of circular marks on left pleural field; I, idem detail of abnormality in left pleural field. Scale bars: A-G, $1.0 \mathrm{~cm} ; \mathrm{H}, \mathrm{I}, 0.5 \mathrm{~cm}$. 
TABLE 1. - List of dalmanitid trilobites recorded from the Devonian of southwestern Gondwana (Malvinokaffric Realm), indicating dorsal spinosity.

\begin{tabular}{|c|c|c|c|c|c|c|}
\hline Dalmanitid taxa & Age & $\begin{array}{l}\text { Units with } \\
\text { records }\end{array}$ & $\begin{array}{l}\text { Geographic } \\
\text { occurrence }\end{array}$ & $\begin{array}{l}\text { Dorsal } \\
\text { spinosity }\end{array}$ & References & Pattern of spines \\
\hline $\begin{array}{l}\text { Amazonaspis } \\
\text { maecurua (Clarke, } \\
\text { 1890) }\end{array}$ & Eifelian & $\begin{array}{l}\text { Maecurú } \\
\text { Formation }\end{array}$ & Brazil & No & $\begin{array}{l}\text { Carvalho \& } \\
\text { da Fonseca } 2007\end{array}$ & Absent. Thorax unknown \\
\hline $\begin{array}{l}\text { Chacomurus } \\
\text { confragosus } \\
\text { (Braniša \& Vaněk, } \\
\text { 1973) }\end{array}$ & $\begin{array}{l}\text { Lochkovian- } \\
\text { Emsian }\end{array}$ & $\begin{array}{l}\text { Lower Belén } \\
\text { Formation, } \\
\text { Chacoma }\end{array}$ & Bolivia & No & $\begin{array}{l}\text { Braniša \& Vaněk } \\
\text { 1973; Holloway \& } \\
\text { carvalho } 2010\end{array}$ & $\begin{array}{l}\text { Thorax unknown. Pygidium only } \\
\text { with marginal spines }\end{array}$ \\
\hline $\begin{array}{l}\text { Dalmanites } \\
\text { patacamayensis } \\
\text { Kozłowski, } 1923\end{array}$ & $\begin{array}{l}\text { Early } \\
\text { Devonian }\end{array}$ & $\begin{array}{l}\text { Sica-Sica } \\
\text { Formation }\end{array}$ & Bolivia & No & Kozłowski 1923 & Absent \\
\hline $\begin{array}{l}\text { Dalmanitoides } \\
\text { accola (Clarke, } \\
\text { 1913) }\end{array}$ & $\begin{array}{l}\text { Early } \\
\text { Devonian }\end{array}$ & $\begin{array}{l}\text { Ponta grossa } \\
\text { Formation }\end{array}$ & Brazil & Yes & $\begin{array}{l}\text { Rustán \& Vaccari } \\
2012\end{array}$ & $\begin{array}{l}\text { One spine on occipital ring. In pairs } \\
\text { on some pygidial axial rings. Irregularly } \\
\text { distributed on posterior pleural bands. }\end{array}$ \\
\hline $\begin{array}{l}\text { Dalmanitoides } \\
\text { boehmi (Knod, } \\
\text { 1908) }\end{array}$ & $\begin{array}{l}\text { Pragian- } \\
\text { Emsian }\end{array}$ & $\begin{array}{l}\text { Tarabuco and } \\
\text { Talacasto } \\
\text { Formation }\end{array}$ & $\begin{array}{r}\text { Bolivia and } \\
\text { Argentina }\end{array}$ & Yes & $\begin{array}{l}\text { Rustán \& Vaccari } \\
2012\end{array}$ & $\begin{array}{l}\text { Two to four spines on thoracic posterior } \\
\text { pleural bands }\end{array}$ \\
\hline $\begin{array}{l}\text { Dalmanitoides } \\
\text { drevermanni } \\
\text { (Thomas, 1906) }\end{array}$ & $\begin{array}{l}\text { Pragian- } \\
\text { Emsian }\end{array}$ & $\begin{array}{l}\text { Talacasto } \\
\text { Formation }\end{array}$ & Argentina & Yes & $\begin{array}{l}\text { Rustán \& Vaccari } \\
2012\end{array}$ & $\begin{array}{l}\text { One medial spine and two lateral on } \\
\text { occipital ring. Little ones on posterior } \\
\text { cephalic border. Four on thoracic axial } \\
\text { rings, symetrically located. In pairs on } \\
\text { pygidial axial rings. Irregularly distributed } \\
\text { on posterior pleural bands }\end{array}$ \\
\hline $\begin{array}{l}\text { Dalmanitoides } \\
\text { scutata (Braniša \& } \\
\text { Vaněk, 1973) }\end{array}$ & Early & $\begin{array}{l}\text { Gamoneda } \\
\text { Formation, } \\
\text { Gamoneda- } \\
\text { Curuyo }\end{array}$ & Bolivia & Yes & $\begin{array}{l}\text { Edgecombe 1993; } \\
\text { Rustán \& Vaccari } \\
2012\end{array}$ & Spines in pairs on thoracic axial rings \\
\hline $\begin{array}{l}\text { Fenestraspis } \\
\text { amauta Braniša \& } \\
\text { Vaněk, } 1973\end{array}$ & $\begin{array}{l}\text { Pragian- } \\
\text { Emsian }\end{array}$ & $\begin{array}{l}\text { Lower Belén } \\
\text { Formation, } \\
\text { Chacoma }\end{array}$ & Bolivia & Yes & $\begin{array}{l}\text { Holloway \& } \\
\text { Carvalho } 2009\end{array}$ & $\begin{array}{l}\text { Spines in pairs on axial parts of L1-L3. } \\
\text { One medial and two lateral ones on } \\
\text { occipital ring. Some on base of genal } \\
\text { spines. In pairs on thoracic axial rings. In } \\
\text { pairs on pygidial axial rings, and isolated } \\
\text { ones on distal part (and in some cases } \\
\text { also medial) of posterior pleural bands }\end{array}$ \\
\hline $\begin{array}{l}\text { Francovichia } \\
\text { branisi (Wolfart, } \\
\text { 1968) }\end{array}$ & $\begin{array}{l}\text { Early } \\
\text { Devonian }\end{array}$ & $\begin{array}{l}\text { Lower Belén } \\
\text { Formation, } \\
\text { Limabamba }\end{array}$ & Bolivia & No & $\begin{array}{l}\text { Braniša \& Vaněk } \\
1973\end{array}$ & Absent. Thorax unknown \\
\hline $\begin{array}{l}\text { Francovichia clarkei } \\
\text { (Ulrich, 1893) }\end{array}$ & $\begin{array}{l}i \text { Emsian- } \\
\text { Eifelian }\end{array}$ & $\begin{array}{l}\text { Icla Formation } \\
\text { and Gydo } \\
\text { Formation }\end{array}$ & $\begin{array}{l}\text { Bolivia and } \\
\text { South Africa }\end{array}$ & No & Cooper 1982 & Absent \\
\hline $\begin{array}{l}\text { "Kasachstania" } \\
\text { gerardoi } \\
\text { Edgecombe \& } \\
\text { Ramsköld, } 1994\end{array}$ & $\begin{array}{l}\text { Ludlow- } \\
\text { Lochkovian }\end{array}$ & $\begin{array}{l}\text { Los Espejos } \\
\text { Formation } \\
\text { and Catavi } \\
\text { Formation }\end{array}$ & $\begin{array}{l}\text { Argentina and } \\
\text { Bolivia }\end{array}$ & No & $\begin{array}{l}\text { Edgecombe \& } \\
\text { Ramsköld } 1994\end{array}$ & Absent \\
\hline $\begin{array}{l}\text { Ivanites leonorae } \\
\text { n. gen, n. sp. }\end{array}$ & $\begin{array}{l}\text { Lochkovian- } \\
\text { Pragian }\end{array}$ & $\begin{array}{l}\text { Talacasto } \\
\text { Formation }\end{array}$ & Argentina & No & This current work & Absent \\
\hline $\begin{array}{l}\text { Aguaditaspis } \\
\text { mediaspina } \\
\text { n. gen, n. sp. }\end{array}$ & $\begin{array}{l}\text { Lochkovian- } \\
\text { Pragian }\end{array}$ & $\begin{array}{l}\text { Talacasto } \\
\text { Formation }\end{array}$ & Argentina & Yes & This current work & $\begin{array}{l}\text { One spine on at least one thoracic } \\
\text { axial ring. One on anteriormost } \\
\text { pygidial axial rings }\end{array}$ \\
\hline $\begin{array}{l}\text { New genus and } \\
\text { species of } \\
\text { Dalmanitidae }\end{array}$ & $\begin{array}{l}\text { Lochkovian- } \\
\text { Pragian }\end{array}$ & $\begin{array}{l}\text { Talacasto } \\
\text { Formation }\end{array}$ & Argentina & Yes & This current work & $\begin{array}{l}\text { Cephalon and thorax unknown. } \\
\text { Spines in pairs on axial rings (except } \\
\text { posterior ones). Small ones between } \\
\text { or lateral to these pairs on axial rings. } \\
\text { Irregularly distributed on anterior pleural } \\
\text { bands. Small ones on anteriormost } \\
\text { posterior pleural bands }\end{array}$ \\
\hline
\end{tabular}

to the Devonian of central Kazakhstan (Randolfe et al. 2020). The excluded specimens from other locations were either assigned to other unrelated genera or pointed out for pending further taxonomic revision (Randolfe et al. 2020).

Table 1 summarizes the dalmanitid trilobites recorded in basins of the Malvinokaffric Realm, excluding some poorly known records which should be considered nomina dubia.
Of the total taxa reliably recognized, 9 genera ( $90 \%$ of the total), and 13 species (more than $90 \%$ of the total) are endemic of the Malvinokaffric Realm. Only Dalmanites seems to be a widely distributed taxon, but some referred specimens, mainly from Bolivia, were never revised after their original assignment (Kozłowski 1923) and deserve a thorough revision. Other putative Dalmanites, from the 
A

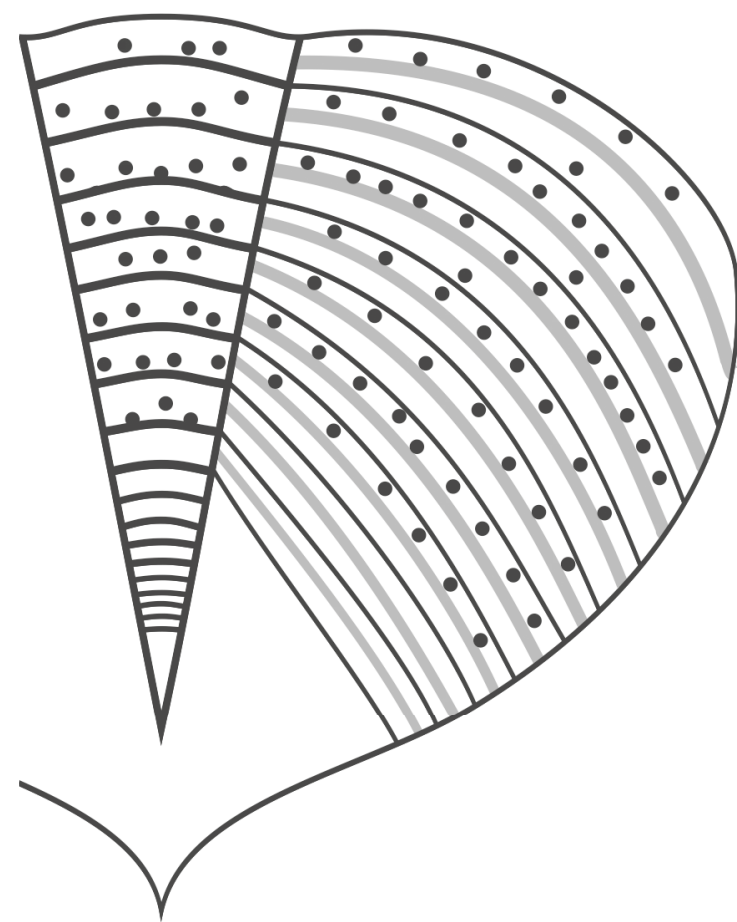

C

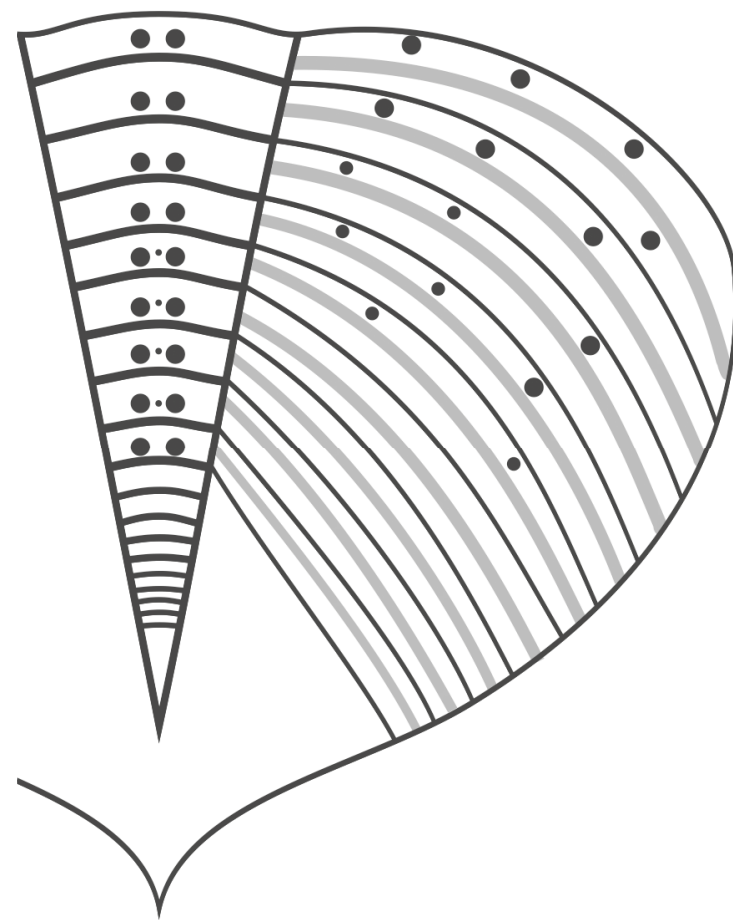

$\mathrm{B}$

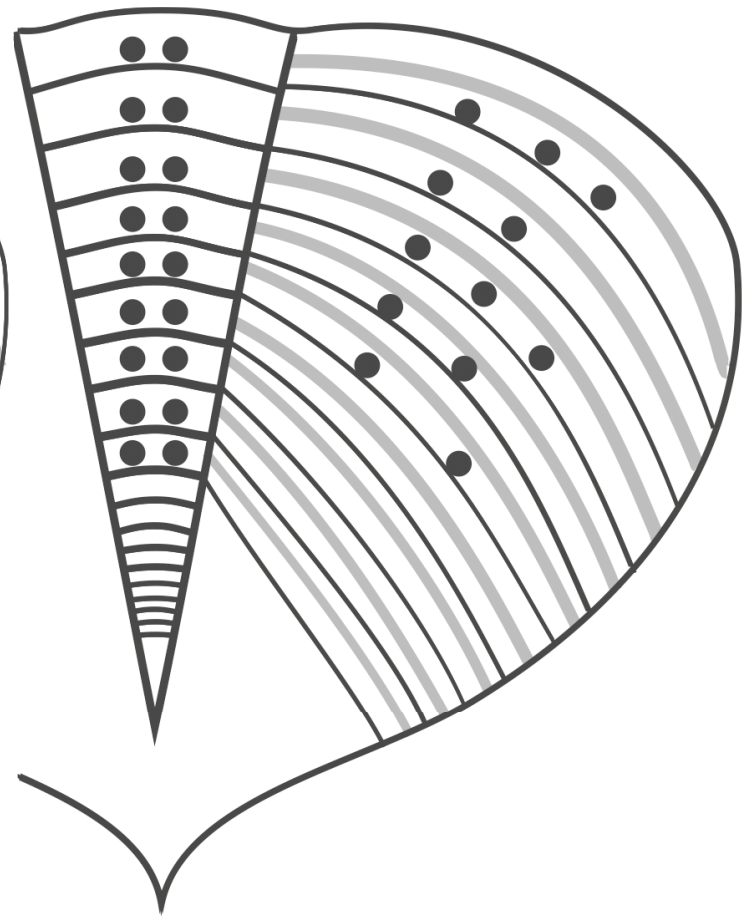

D

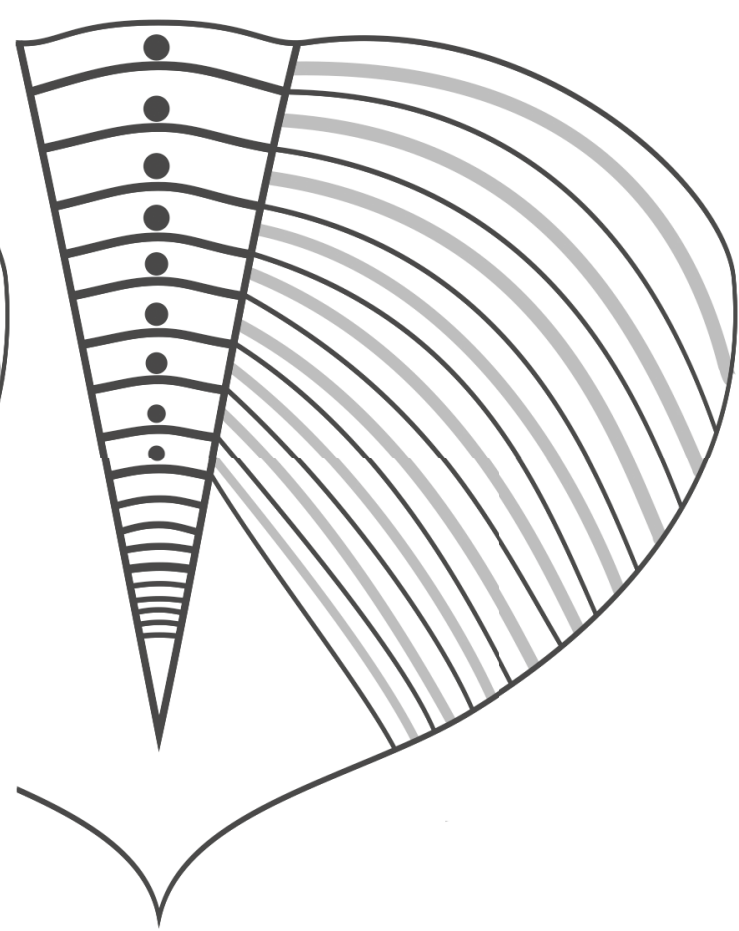

FIG. 8. - Schematic drawings of main dorsal spine patterns (only the location of base of spines is shown) among dalmanitids: A, pattern of Zlichovaspis (Zlichovaspis) spinifera spinifera (Barrande, 1852) from the Lower Devonian of the Prague Basin; B, pattern of Dalmanitoides drevermanni (Delo, 1935) from the Lower Devonian of Southern Gondwana; C, pattern of a new genus and species of Dalmanitidae from the Lower Devonian of Southern Gondwana; D, pattern of Trypaulites calypso (Hall, 1861) from the Devonian of the United States. Spines are not necessarily distributed in perfect longitudinal rows.

Middle Devonian of the Maecurú Formation, Brazil, were originally described by Clarke (1890). They were considered as indeterminate taxa with calmoniid affinities by Eldredge $\&$ Ormiston (1979) and are not included in the table. Dalmanites? infractus Clarke, 1890, on the other hand, was erected based on scarce material that is considered lost (Ponciano 2011), and consequently, is also excluded for the table.

The new dalmanitid genera reported herein include Ivanites n. gen., Aguaditaspis n. gen. and a new genus of Dalmanitidae, all restricted to the Lower Devonian (Lochkovian-Pragian) 
from the Precordillera Basin, Argentina. These taxa contribute to the idea of endemism and diversification of this family in Malvinokaffric basins.

\section{THE SPINOSITY IN DEVONIAN DALMANITID TRILOBITES} AS EVIDENCE OF PREDATION PRESSURE

Two of the new taxa described herein (Aguaditaspis n. gen. and the new genus of Dalmanitidae) exhibit dorsal spinosity, a very rare character among dalmanitids.

Table 1 indicates the presence of dorsally projected spinosity in the dalmanitids recorded in Malvinokaffric basins. As many as four genera ( $40 \%$ of the total genera) and seven species (50\% of total species) exhibit a clear dorsal spinosity in this paleobiogeographic region.

Spines in invertebrate prey-groups are usually interpreted as passive (morphologic) defenses (Vermeij 2002; Mikolajewski \& Rolff 2004; Willman 2007; Ito et al. 2016). Their evolutionary dynamics are linked to the ecological context of an increase of predation pressure or predator evolutionary bursts (Leighton 2003; Johansson \& Mikolajewski 2008; Nagel-Myers et al. 2009).

For trilobites, dorsally projected spines have been proposed for different functions including their use as a sensory apparatus or to fight in intraspecific contests for access to mates (Knell \& Fortey 2005). More commonly, dorsal spines have been proposed for defensive functions, as protection of the blind spots against predators (Brett \& Walker 2002), to dissuade them (Clarkson \& Ahlberg 2002) or for attachment of algae that help camouflage (Schraut 2000). Spinosity patterns composed of robust dorsal spines densely distributed are well-recorded in trilobites from low paleolatitudes during the middle Paleozoic, as is the case in the Asteropyginae, Aulacopleuridae, Odontopleuridae and Scutelluidae (Chatterton et al. 2006; Feist \& Chatterton 2015). In the case of dalmanitids, an Ordovician-Devonian cosmopolitan group characterized by a conservative bauplan, dorsal spinosity is a very unusual character only documented in the Devonian.

This dorsal spinosity is organized in some main distinct patterns (Fig. 8). For example, spines are common in some species of Zlichovaspis Přybil \& Vaněk, 1971, a widely distributed genus, but absent in the basins of southern Gondwana. These spines are narrow-based and irregularly distributed on the pygidial axis and pleurae, commonly more abundant on anterior pleural bands. On axial rings, spines have a stochastic distribution, with three to five on each ring (Fig. 8A). Size, morphology and abundance of these spines are considered diagnostic at the specific level. Some species, like $Z$. (Z.) tuberculata (Hawle \& Corda, 1847), have spines defining three to five irregular longitudinal rows along the axis (Budil et al. 2009). Distribution of thoracic spines is irregular, not necessarily similar to that of the pygidium of the same specimen. The cephalon exhibits thorn-like tubercles densely distributed on glabellar and palpebral lobes, occipital ring and genal area. Some species assigned to Odontochile Hawle \& Corda, 1847 , such as $O$. phacoptyx (Hall \& Clarke, 1888), share a similar distribution of spines or spiny tubercles, although their spines are usually dorsally shorter than that of Zlichovaspis.
Dalmanitoides, Fenestraspis, from southern Gondwana, and Roncellia perceensis (Clarke, 1905) from Laurussia, bear robust dorsal paired spines or tubercles on several pygidial axial rings and irregularly distributed ones on posterior pleural bands (Fig. 8B). This pattern is similar to the new genus and species of Dalmanitidae reported herein. Nevertheless, this taxon has spines on anterior rather than posterior pleural bands (Fig. 8C). We considered this pattern as not homologous with the one of Dalmanitoides and Fenestraspis. In addition, some little spines are insinuated on the first posterior pleural bands of the new genus and species of Dalmanitidae and two or more additional much smaller are placed laterally on axial rings or between the pair of major spines.

In some Dalmanitoides species and probably in Fenestraspis the thoracic pattern of spines is similar to pygidial ornamentation, with additional dorsal spines more abaxially placed on axial rings. In both genera the presence of cephalic pairs of spines on L1-L3, one medial spine in the occipital ring and additional spines on the cephalic posterior border are common.

On the other hand, Aguaditaspis mediaspina n. gen., n. sp. bears only a medial dorsal spine on pygidial axial rings, while pleural bands are free of spines (Fig. 8D). This is a rare pattern similar to Trypaulites calypso (Hall, 1861) from the Lower Devonian of North America. Aguaditaspis n. gen. has at least one thoracic axial ring, probably the posterior one, with a medial spine (Fig. 5E, F, L).

Another pattern is observed in Erbenochile Alberti, 1981, from the upper Emsian-Eifelian of Morocco and Algeria, a genus considered related to Dalmanitids (Bignon \& Crônier 2014). Robust pointed spines are located medially on each axial ring and little spines (6-8) are distributed on each thoracic, and the anteriormost pygidial posterior pleural bands. Some little dorsal tubercles are also present on axial rings, more distally than medial spine, particularly prominent in E. issoumourensis Chatterton \& Gibb, 2010. One robust medial spine is also located in the occipital ring and additional spines on the posterior cephalic border of this genus.

We do not support a common phylogenetic origin for all these different spine patterns since morphological differences indicate that all the involved taxa do not conform to a monophyletic group. Given this, each pattern of dorsally projected spines should be interpreted as parallel evolutionary acquisitions (analogies) of dalmanitids during the Devonian.

The Devonian is an important period for the fossil record of predation. A number of works suggests a general rising of new and more abundant predators during this period. Their ecological/evolutionary impact has been characterized as the mid Paleozoic Marine Revolution (Signor \& Brett 1984; Brett $\&$ Walker 2002) and is particularly clear among Devonian nektonic carnivorous like cephalopods and fishes (Klug et al. 2010). The defensive evolutionary response in preys, mainly represented by spinosity, has been treated in several works focusing on brachiopods, bivalves and crinoids from the Silurian to the Carboniferous (Leighton 2003; Baumiller \& Gahn 2004; Nagel-Myers et al. 2009). None of the studies were centered on how this process affected trilobites, apart from these being considered a main prey-group during the 
Paleozoic. Robust spines of Middle Paleozoic trilobites have been interpreted as defensive structures tangentially in publications focused on taxonomic discussions and assignments (e.g. Chatterton \& Gibb 2010; Feist \& Chatterton 2015).

A latitudinal gradient of predation pressure has been recognized, estimated to be lower at high paleolatitudes (Dudley \& Vermeij 1978; Leighton 1999; Harper \& Peck 2016). A common explanation is that the warmer temperatures in tropics led to a greater importance of biotic interactions including predation, as a result of a sustainable abundance of potential preys (Schemske et al. 2009). The presence of a latitudinal gradient of predation pressure is supported by studies that highlight lower predation at high latitudes (Sanford et al. 2003) and more diverse predation-prey interactions and evidences of failed predation at lower latitudes (Kelley \& Hansen 2007). In Devonian strophomenid brachiopods this hypothesis is supported by the latitudinal variation of ornamentation, decreasing at higher paleolatitudes (Leighton 1999). A latitudinal gradient of predation-prey interactions in accordance with this was also recognized for extant brachiopods using frequencies of samples with repaired damage (Harper \& Peck 2016). A more complex analysis at a less global scale recognized a latitudinal gradient in extant bivalves from the United States (Alexander \& Dietl 2001). This work used different indexes for measuring predation intensity, centered on drilling. Those include size of the valves, frequency of incomplete drilling and variety of predation marks. In such a scenario of a recognized latitudinal predation pressure gradient, the presence of so much spinose taxa in the Malvinokaffric Realm (high paleolatitudes) is relevant.

Furthermore, in addition to evidences from dalmanitids, spinosity is also a remarkable feature of other Devonian trilobites from southern Gondwana. Many calmoniids are highly spinose, contributing to their high morphological disparity (Abe \& Lieberman 2009). Spines are also present in other trilobite families, like the homalonotids Burmeisterella braziliensis de Carvalho, 2005 and Burmeisteria herschelii (Murchison, 1839). Moreover, the phacopids, a group as morphologically conservative as dalmanitids, include spinose representatives like Echidnops taphomimus Rustán \& Balseiro, 2016. This taxon is otherwise particularly interesting because performed the habit of infaunal molting, a unique behavior, interpreted as an active defense to avoid predators by molting under the sediment (Rustán et al. 2011b). This taxon co-occurs in the very same layers than the newly reported dalmanitids of the Talacasto Formation herein.

However, evidence of predators in Malvinokaffric basins is poor. Fishes (sensu lato), for example, are only known from very scarce records in Bolivia, South Africa, Malvinas/ Falkland Islands and Brazil (Janvier \& Suarez-Riglos 1986; Anderson et al. 1999; Maisey et al. 2002; Janvier \& Maisey 2010). To explain such scarcity, Janvier \& Maisey (2010) suggested a preservational bias. In Argentina, just mentions of remains were reported (Frenguelli 1951; Janvier \& SuarezRiglos 1986; Rustán \& Balseiro 2016). Cephalopods, in turn, once interpreted as nearly absent from the Malvinokaffric Realm (Boucot \& Racheboeuf 1993; Bosetti et al. 2010), are nowadays been reported from the Talacasto Formation (Cichowolski \& Rustán 2017, 2020).

In this hypothesis of rising predation-prey interactions, it is worth to mention the abnormality on last three pleurae of the left side of specimen CEGH-UNC 27422 (Dalmanitidae, new genus and species, Fig. 7I), postuled as a possible postpredation mark. Additional evidences from the same unit studied herein, has recently been reported from a pygidial axial ring of a specimen of Burmeisteria notica (Clarke, 1913), considered as a post-predation mark (Rustán et al. 2020).

The record of Devonian spines in trilobite families usually devoid of them, like the dalmanitids and phacopiids along with putative records of attacks, would support a more intense predation-prey interaction than previously thought in Malvinokaffric basins. Although indirect, these evidences account for a clear evolutionary/ecological impact of predation over preys, even in paleolatitudes where predation should be less observable according the latitudinal gradient. Our evidence is consistent with the major event of increasing predation pressure in all marine Devonian ecosystems, predicted by the hypothesis of the mid Paleozoic Marine Revolution.

\section{Acknowledgements}

R. Haude and I. Tapia help in paleontological surveys in Precordillera Argentina. We would also like to thank Eng. Roal Zárate from Compañía Minera del Pacífico (El Refugio limestone quarry near Jáchal), for allowing us to access Loma de los Piojos locality. This work benefited from the helpful improvement of the English and constructive review of the manuscript made by M. Ebach and A. van Viersen, and the associate editor, Annalisa Ferretti. We thank the Consejo Nacional de Investigaciones Científicas y Técnicas (CONICET) and the Universidad Nacional de Córdoba for providing the support and facilities used in this investigation. This is a contribution to PUE 2016-CONICET-CICTERRA. Financial support was provided by University of La Rioja (projects PIC) and the Agencia Nacional de Promoción Científica y Tecnológica (ANPyT-FONCYT) project BID PICT-2017-3095 granted to J. J. Rustán.

\section{REFERENCES}

ABE F. R. \& Lieberman B. S. 2009. - The nature of evolutionary radiations: a case study involving Devonian trilobites. Evolutionary Biology 36 (2): 225-234. https://doi.org/10.1007/s11692009-9060-0

Abe F. R. \& Lieberman B. S. 2012. — Quantifying morphological change during an evolutionary radiation of Devonian trilobites. Paleobiology 38 (2): 292-307. https://doi.org/10.1666/10047.1

AlBerTi G. K. B. 1981. - Beziehunger zwischen "herzynischen" Trilobitenfauna aus NW-Marokko und Deutschland (Unter- und Mittel-Devon). Natur und Museum 111: 362-369.

Alexander R. R. \& DieTl G. P. 2001. - Latitudinal trends in naticid predation on Anadara ovalis (Bruguière, 1789) and Divalinga quadrisulcata (Orbigny, 1842) from New Jersey to the Florida Keys. American Malacological Bulletin 16 (1-2): 179-194. https://www.biodiversitylibrary.org/page/45999691 
Anderson M. E., Almond J. E., Evans F. J. \& Long J. A. 1999. Devonian (Emsian-Eifelian) fish from the Lower Bokkeveld Group (Ceres Subgroup), South Africa. Journal of African Earth Sciences 29 (1): 179-193. https://doi.org/10.1016/S0899-5362(99)00088-3

Astini A. R. 1991. - Sedimentología de la Formación Talacasto: plataforma fangosa del Devónico precordillerano, provincia de San Juan. Revista de la Asociación Geológica Argentina 44 (3-4): 277-294.

BARRANDE J. 1852. - Systême Silurien du centre de la Bohême: Ière Partie: Recherches Paléontologiques. Vol. I. Planches. Crustacés: Trilobites (vol. 1). Chez l'auteur et éditeur, Prague, 935 p. https://doi.org/10.5962/bhl.title.14776

BAUMILler T. K. \& GAHN F. J. 2004. — Testing predator-driven evolution with Paleozoic crinoid arm regeneration. Science 305 (5689): 1453-1455. https://doi.org/10.1126/science.1101009

Benedetto J. L., Racheboeuf P. R., Herrera Z., Brussa E. \& Toro B. A. 1992. - Brachiopodes et biostratigraphie de la Formation Los Espejos, Siluro-Dévonien de la Précordillère (NW Argentine). Geobios 25 (5): 599-637. https://doi. org/10.1016/0016-6995(92)80101-I

Bengtson P. 1988. - Open nomenclature. Palaeontology 31 (1): 223-227.

Bicknell R. D., Paterson J. R. \& Hopkins M. J. 2019. - A trilobite cluster from the Silurian Rochester Shale of New York: predation patterns and possible defensive behavior. American Museum Novitates 3937: 1-16. https://doi.org/10.5531/sd.sp.35

BIgnON A. \& CRÔNIER C. 2014. - The systematics and phylogeny of the Devonian subfamily Asteropyginae (Trilobita: Phacopida). Journal of Systematic Palaeontology 12 (6): 637-668. https://doi.org/10.1080/14772019.2013.804008

Bosetti E. P., Horodyski R. S., Zabini C., Matsumura W. M. K. \& Penteado A. C. 2010. - Ocorrência de fenótipos subnormais no limite Neoeifeliano/ Eogivetiano, Tibagi, estado do Paraná: implicaçóes tafonômicas e paleossinecológicas. Boletim do Museu Paraense Emílio Goeldi-Ciências Naturais 5 (2): 135-149.

Boucot A. J. \& Racheboeuf P. R. 1993. - Biogeographic summary of the Malvinokaffric Realm Silurian and Devonian fossils, in SuAREZ-Soruco R. (ed.), Fósiles y facies de Bolivia II. Invertebrados y Paleobotánica: Revista Técnica de Yacimientos Petroliferos Fiscales Bolivianos 13-14: 71-75.

Bracaccini O. I. 1949. - El perfil de Tambolar. Revista de la Asociación Geológica Argentina 4 (3): 165-179.

BRANIŠA L. \& VANĚK J. 1973. - Several new trilobite genera of the superfamily Dalmanitacea Vogdes, 1890 in the Devonian of Bolivia. Vestnik Ústredního ústavu geologického 48: 95-101.

BretT C. E. \& Walker S. E. 2002. - Predators and predation in Paleozoic marine environments. The Paleontological Society Papers 8: 93-118. https://doi.org/10.1017/S1089332600001078

Budil P., HÖrbinger F. \& MENCL R. 2009. - Lower Devonian dalmanitid trilobites of the Prague Basin (Czech Republic). Earth and Environmental Science Transactions of the Royal Society of Edinburgh 99 (2): 61-100. https://doi.org/10.1017/S1755691009006161

Bustos U. D. \& Astini A. R. 1997. - Formación Punta Negra: análisis secuencial y evolución de la Cuenca Devónica Precordillerana. Revista de la Asociación Argentina de Sedimentología 4 (2): 97-111.

CAmpbell K. S. W. 1977. - Trilobites of the Haragan, Bois d'Arc and Frisco Formations (Early Devonian), Arbuckle Mountains region, Oklahoma. University of Oklahoma. Bulletin of the Oklahoma Geological Survey 123: 1-227.

Carrera M. G., Montoya E., Rustán J. J. \& Halpern K. 2013. - Silurian-Devonian coral associations across a sequence stratigraphic boundary in the Argentine Precordillera. Geological Journal 48 (2-3): 256-269. https://doi.org/10.1002/gj.1332

Carvalho M. G. P. DE 2005. - First occurrence of Burmeisterella (Trilobita, Homalonotidae) from the Devonian of Brazil (Parecis Basin), with description of a new species. Archivos do Museu Nacional do Rio de Janeiro 63: 451-458.
Carvalho M. G. P. \& Fonseca V. M. M. De 2007. — The Trilobite "Dalmanites" maecurua (Middle Devonian, Amazon Basin, Brazil) and the New Genus Amazonaspis (Synphoriidae). American Museum Novitates 3591: 1-14. https://doi.org/bjwrfd

Chatterton B. D. \& GibB S. 2010. — Latest Early to Early Middle Devonian Trilobites from the Erbenochile Bed, Jbel Issoumour, Southeastern Morocco. Journal of Paleontology 84 (6): 1188-1205. https://doi.org/10.2307/40925991

Chatterton B., Fortey R. A. \& Brett K. 2006. — Trilobites from the upper Lower to Middle Devonian Timrhanrhart Formation, Jbel Gara el Zguilma, southern Morocco. Palaeontographica Canadiana 25 (25): 1-177.

CICHOWOLSKI M. \& RUSTÁN J. J. 2017. — First report of Devonian bactritids (Cephalopoda) from South America: paleobiogeographic and biostratigraphic implications. Journal of Paleontology 91 (3): 417-433. https://doi.org/10.1017/jpa.2017.17

CICHOWOLSKI M. \& RUSTÁN J. J. 2020. — Lamellorthoceratid cephalopods in the cold waters of southwestern Gondwana: Evidences from the Lower Devonian of Argentina. Acta Paleontologica Polonica 65 (2): 305-312. https://doi.org/10.4202/ app.00699.2019

Clarke J. M. 1890. — As trilobitas do grez de Ereré e Maecurú: Estado do Pará, Brazil. Imprensa Nacional 9: 1-58.

Clarke J. M. 1905. — Percé, a brief sketch of its geology, in: Report of the State Paleontologist 1903. New York State Museum Bulletin 80: 134-172.

Clarke J. M. 1913. - Fosseis devonianos do Paraná. Typ. annexa á Directoria do Serviço de estatistica, Monographia do servicio geológico e mineralógico do Brasil 1, Río de Janeiro, 353 p.

ClARKSON E. N. \& AHLBERG P. 2002. - Ontogeny and structure of a new, miniaturised and spiny olenid trilobite from southern Sweden. Palaeontology 45 (1): 1-22. https://doi.org/10.1111/14754983.00224

Cooper M. R. 1982. - A revision of the Devonian (EmsianEifelian) Trilobita from the Bokkeveld Group of South Africa. Annals of the South African Museum 89: 1-174. https://www. biodiversitylibrary.org/page/40697150

CUERDA A. J. 1965. - Monograptus leintwardinensis var. incipiens Wood en el Silúrico de la Precordillera. Ameghiniana 4 (5): 171-177.

Delo D. M. 1935. - A revision of the phacopid trilobites. Journal of Paleontology 9: 402-420. https://www.jstor.org/stable/1298148

DowDing E. M. \& EBACH M. C. 2018. - An interim global bioregionalisation of Devonian areas. Palaeobiodiversity and Palaeoenvironments 98: 527-547. https://doi.org/10.1007/s12549018-0319-2

Dudley E. C. \& Vermeij G. J. 1978. - Predation in time and space: drilling in the gastropod Turritella. Paleobiology 4 (4): 436441. https://doi.org/10.1017/S0094837300006175

Edgecombe G. D. 1991. — The Silurian dalmanitid trilobite Glyptambon Holloway: new species from Tennessee and Illinois. Journal of Paleontology 65 (2): 294-300. https://doi.org/10.1017/ S0022336000020527

Edgecombe G. D. 1993. - A revision of the Devonian dalmanitid trilobite Gamonedaspis. Revista Técnica de Yacimientos Petroliferos Fiscales Bolivianos 2: 13-14, 161-166.

Edgecombe G. D. \& RAMSKÖLD L. 1994. - Earliest Devonian phacopide trilobites from central Bolivia. Paläontologische Zeitschrift 68 (3): 397-410. https://doi.org/10.1007/BF02991351

Eldredge N. \& Ormiston A. R. 1979. - Biogeography of Silurian and Devonian trilobites of the Malvinokaffric Realm, in GraY J. \& Boucot H. J. (eds.), Historical Biogeography, Plate Tectonics, and the Changing Environment. Oregon State University Press, Corwallis, Oregon: 147-167.

ELDREDGE N. \& BRANIŠA L. 1980. - Calmoniid trilobites of the Lower Devonian Scaphiocoelia zone of Bolivia, with remarks on related species. Bulletin of the American Museum of Natural History 165, article 2. http://hdl.handle.net/2246/319 
Feist R. \& Chatterton B. D. 2015. - Kolihapeltine trilobites, the spiniest scutelluids from the eastern Anti-Atlas (Morocco, Early Devonian): evolution, environment and classification. Papers in Palaeontology 1 (3): 255-287. https://doi.org/10.1002/ spp2.1015

Frenguelli J. 1951. - Floras devónicas de la Precordillera de San Juan. Revista de la Asociación Geológica Argentina 6 (2): 83-94.

García Muro V. J., Rubinstein C. V. \& Rustán J. J. 2017. Early Devonian organic-walled phytoplankton and miospores from the Precordillera Basin of San Juan, Argentina: biostratigraphic and paleobiogeographic implications. Palynology 41: 138-157. https://doi.org/10.1080/01916122.2017.1366191

García Muro V. J., Rubinstein C. V., Rustán J. J. \& SteeMANS P. 2018. - Palynomorphs from the Devonian Talacasto and Punta Negra Formations, Argentinean Precordillera: New biostratigraphic approach. Journal of South American Earth Sciences 86: 110-126. https://doi.org/10.1016/j. jsames.2018.06.009

HALL J. 1861. - Preliminary notice of the Trilobites and other Crustacea of the Upper Helderberg, Hamilton and Chemung Groups. Contributions to Paleontology. Continuation of Appendix C. Descriptions of new species of fossils, from the Upper Helderberg, Hamilton and Chemung Groups. Annual Report of the Regents University, State of New York 14: 54-84.

Hall J. \& Clarke J. M. 1888. - Descriptions of the trilobites and other Crustacea of the Oriskany, Upper Helderberg, Hamilton, Portage, and Chemung, and Catskill groups. Paleontology of New York 7, $236 \mathrm{p}$.

HARPER E. M. \& PECK L. S. 2016. — Latitudinal and depth gradients in marine predation pressure. Global Ecology and Biogeography 25 (6): 670-678. https://doi.org/10.1111/geb.12444

Hawle I. \& CoRda A. J. 1847. — Prodrom einer Monographie der böhmischen Trilobiten. 176 p., pls 1-7.

Herrera Z. A. 1993. - Nuevas precisiones sobre la edad de la Formación Talacasto (Precordillera Argentina) en base a su fauna de braquiópodos. Actas del 12do Congreso Geológico Argentino y 2do Congreso de Exploración de Hidrocarburos 2: 289-295.

Herrera Z. A. \& Bustos U. D. 2001. - Braquiópodos devónicos de la Formación Punta Negra, en el perfil del Río de las Chacritas, Precordillera Argentina. Ameghiniana 38 (4): 367-374.

Holloway D. J. 1981. - Silurian dalmanitacean trilobites from North America and the origins of the Dalmanitinae and Synphoriinae. Palaeontology 24: 695-731.

Holloway D. J. \& Carvalho M. G. P. De 2009. - The extraordinary trilobite Fenestraspis (Dalmanitidae, Synphoriinae) from the Lower Devonian of Bolivia. Palaeontology 52 (4): 933-949. https://doi.org/10.1111/j.1475-4983.2009.00878.x

Holloway D. J. \& Carvalho M. G. P. DE 2010. - The trilobite Chacomurus (Dalmanitidae, Synphoriinae) from the Lower Devonian of Bolivia. Memoirs of the Association of Australasian Palaeontologists 39: 71-83.

Holloway D. J. \& RustÁn J. J. 2012. — The Trilobite Reedops (Phacopidae) in the Lower Devonian of Argentina (Malvinokaffric Realm). Journal of Paleontology 86 (2): 253-257. https://doi. org/10.1666/11-082.1

Ito F., Taniguchi K. \& Billen J. 2016. — Defensive function of petiole spines in queens and workers of the formicine ant Polyrhachis lamellidens (Hymenoptera: Formicidae) against an ant predator, the Japanese treefrog Hyla japonica. Asian Myrmecology 8: 81-86. https://doi.org/10.20362/am.008014

JanvieR P. \& SuAREZ-Riglos M. 1986. - The Silurian and Devonian vertebrates of Bolivia. Bulletin de l'Institut Français d'Études andines 15 (3-4): 73-114.

JANVIER P. \& MAISEY J. G. 2010. — The Devonian vertebrates of South America and their biogeographical relationships, in ELLIOT D. K., Maisey J. G., Yu X. \& MiaO D. (eds), Morphology, Phylogeny and Paleobiogeography of Fossil Fishes. Verlag Dr. Friedrich Pfeil, München: 431-459.
Johansson F. \& Mikolajewski D. J. 2008. - Evolution of morphological defences, in CÓRDOBA-AgUilar A. (ed.), Dragonflies and damselfies: model organisms for ecological and evolutionary research. Instituto de Ecología, Universidad Nacional Autónoma de México: 127-137. https://doi.org/10.1093/acpr of:oso/9780199230693.003.0010

Kelley P. H. \& Hansen T. A. 2007. - Latitudinal patterns in naticid gastropod predation along the east coast of the United States: a modern baseline for interpreting temporal patterns in the fossil record. Special Publication-SEPM 88: 287-299. https:// doi.org/10.2110/pec.07.88.0287

Klug C., Kroeger B., Kiessling W., Mullins G. L., Servais T., FRÝDA J. \& TURNER S. 2010. - The Devonian nekton revolution. Lethaia 43 (4): 465-477. https://doi.org/10.1111/j.15023931.2009.00206.x

KNell R. J. \& Fortey R. A. 2005. - Trilobite spines and beetle horns: sexual selection in the Palaeozoic?. Biology Letters 1 (2) 196-199. https://doi.org/10.1098/rsbl.2005.0304

KNOD R. 1908. - Devonische Faunen Boliviens, in STEINMANN G. (ed.), Beiträge zur Geologie und Paläontologie von Südamerika. Neues Jahrbuch für Mineralogie. Geology und Paläontology 25. E. Schweizerbart, Stuttgart: 493-600.

KozŁowski R. 1923. - Faune dévonienne de Bolivie. Annales Paleontologie 12: 1-112.

LEIGHTON L. R. 1999. - Possible latitudinal predation gradient in middle Paleozoic oceans. Geology 27 (1): 47-50. https://doi. org/10.1130/0091-7613(1999)027<0047:PLPGIM>2.3.CO;2

LeightON L. R. 2003. — Predation on brachiopods, in Kelley P. H., Kowalewsi M. \& Hansen T. A. (eds), Predator-Prey Interactions in the Fossil Record. Topics in Geobiology. Vol. 20. Springer, Boston: 215-237. https://doi.org/10.1007/978-1-4615-0161-9_9

LESPÉRANCE P. J. 1975. - Stratigraphy and paleontology of the Synphoriidae (Lower and Middle Devonian dalmanitacean trilobites). Journal of Paleontology 49: 91-137. https://www.jstor. org/stable/1303318

Lespérance P. J. \& Bourque P. A. 1971. - The Synphoriinae: an evolutionary pattern of Lower and Middle Devonian trilobites. Journal of Paleontology 45: 182-208.

LieBERMAN B. S. 1993. - Systematics and biogeography of the "Metacryphaeus group" Calmoniidae (Trilobita, Devonian), with comments on adaptive radiations and the geological history of the Malvinokaffric Realm. Journal of Paleontology 67 (4): 549570. https://doi.org/10.1017/S0022336000024902

Lieberman B. S., Edgecombe G. D. \& Eldredge N. 1991. - Systematics and biogeography of the "Malvinella group," Calmoniidae (Trilobita, Devonian). Journal of Paleontology 65 (5): 824-843. https://doi.org/10.1017/S002233600003780X

Maisey J. G., Borghi L. \& CarvalHo M. G. DE 2002. - Lower Devonian fish remains from the Falkland Islands. Journal of Vertebrate Paleontology 22 (3): 708-711. https://doi.org/10.1671/02724634(2002)022[0708:LDFRFT]2.0.CO;2

MaKsimova Z. A. 1972. - New Devonian trilobites of the Phacopoidea. Paleontologicheskij Zhurnal 14: 88-95 [in Russian].

MiKOLAJEWSKI D. J. \& RolfF J. 2004. — Benefits of morphological defence demonstrated by direct manipulation in larval dragonflies. Evolutionary Ecology Research 6 (4): 619-626.

Moore R. C. (ed.). 1959. - Treatise on Invertebrate Paleontology, Part 0, Arthropoda 1. Geological Society of America and University of Kansas Press, Lawrence, 560 p.

MURCHISON R. I. 1839. - The Silurian system, founded on geological researches in the counties of Salop, Hereford, Radnor, Montgomery, Caermarthen, Brecon, Pembroke, Monmouth, Worcester, Gloucester and Stafford; with descriptions of the coalfields and overlying formations. John Murray, London, 768 p. https://doi.org/10.5962/ bhl.title.88029

Nagel-Myers J., Dietl G. P. \& BRETT C. E. 2009. — First report of sublethal breakage-induced predation on Devonian bivalves. Palaios 24 (7): 460-465. https://doi.org/10.2110/palo.2008.p08-136r 
Owen A. W. 1985. - Trilobite abnormalities. Earth and Environmental Science Transactions of The Royal Society of Edinburgh 76 (2-3): 255-272. https://doi.org/10.1017/S0263593300010488

Padula E., Rolleri E., Mingramm A. R., Criado Rogué P. Flores M. A. \& BALDis B. A. 1967. - Devonian of Argentina, in OSWALD D. (ed.), Proceedings of the International Symposium on the Devonian System 2. Canadian Society of Petroleum Geologists, Calgary: 165-199.

PATES S. \& BiCKNell R. D. 2019. - Elongated thoracic spines as potential predatory deterrents in olenelline trilobites from the lower Cambrian of Nevada. Palaeogeography, palaeoclimatology, palaeoecology 516: 295-306. https://doi.org/10.1016/j. palaeo.2018.12.013

Ponciano L. C. M. O. 2011. - Fósseis devonianos da Bacia do Amazonas. Bookess, Sao Paulo, 137 p.

PřıbYL A. \& VANĚK J. 1971. — Phacopina Struve, 1959 (Trilobita) im böhmischen Silur und Devon. Acta Universitatis Carolinae, Geologica 1: 53-68.

Racheboeuf P. R. \& Herrera Z. A. 1994. - Über einige neue silurische und devonische Chonetaceen-Arten (Brachiopoda), und Reklassifizierung anderer Arten (On some new malvinokaffric Silurian and Devonian chonetacean brachiopods and reclassification of others). Neues Jahrbuch für Geologie und Paläontologie, Monateshefte 9: 541-560. https://doi.org/10.1127/ njgpm/1994/1994/541

Randolfe E. A., Rustán J. J. \& Bignon A. 2020. — A taxonomic revision of the Early Devonian dalmanitid trilobite Kasachstania Maksimova, 1972, from central Kazakhstan. Journal of Paleontology 94 (4): 681-695. https://doi.org/10.1017/jpa.2019.108

Richter R. \& Richter E. 1942. — Die Trilobiten der Weismes-Schichten am HohenVenn, mit Bemerkungen über die Malvinocaffrische Provinz: Senckenbergiana 25: 156-179.

RustÁn J. J. 2011. - Trilobites devónicos de la Precordillera Argentina, sistemática, filogenia, paleobiogeografía y bioestratigrafía. $\mathrm{PhD}$ Thesis, Universidad Nacional de Córdoba, 233 p.

Rustán J. J. 2016. — Los trilobites devónicos de Precordillera Argentina: sistemática, filogenia, bioestratigrafía y paleobiogeografía. Revista de la Facultad de Ciencias Exactas, Físicas y Naturales 3: 133-143.

RUSTÁN J. J. \& VACCARI N. E. 2012. - A revision of the Devonian Malvinokaffric dalmanitid trilobite Dalmanitoides Delo, 1935, on the basis of new data from Argentina. Palaeontologia Electronica 15. https://doi.org/10.26879/276

Rustán J. J. \& BALSEIRO D. 2016. — The phacopid trilobite Echidnops taphomimus $\mathrm{n}$. sp. from the Lower Devonian of Argentina: insights into infaunal molting, eye architecture and geographic distribution. Journal of Paleontology 90 (6): 1100-1111. https:// doi.org/10.1017/jpa.2016.108

Rustán J. J., VACCARI N. E. \& Astini R. A. 2011a. - Early Devonian trilobites from the Sierra de las Minitas, northernmost Precordillera (La Rioja Province), Argentina. Ameghiniana 48 (2): 226-242. https://doi.org/10.5710/AMGH.v48i1(335)

Rustán J. J., Balseiro D., Waisfeld B., Foglia R. D. \& VACCARI N. E. 2011b. - Infaunal molting in Trilobita and escalatory responses against predation. Geology 39 (5): 495-498. https://doi.org/10.1130/G31879.1

Rustán J. J., Waisfeld B. G. \& VACCARi N. E. 2020. — The homalonotid trilobite Burmeisteria Salter, 1865 in the Lower Devonian of Argentina: new data in the context of southwestern Gondwana. Journal of Paleontology 94 (3): 498-512. https://doi. org/10.1017/jpa.2019.104

SALTER J. W. 1864. - On some new fossils from the Lingulaflags of Wales. Quarterly Journal of the Geological Society 20 (1-2): 233-241.

SAnford E., Roth M. S., Johns G. C., Wares J. P. \& Somero G. N. 2003. - Local selection and latitudinal variation in a marine predator-prey interaction. Science 300 (5622): 1135-1137. https:// doi.org/10.1126/science.1083437

Schemske D. W., Mittelbach G. G., Cornell H. V., Sobel J. M. \& Roy K. 2009. - Is there a latitudinal gradient in the importance of biotic interactions? Annual Review of Ecology Evolution and Systematics 40 (1): 245-269. https://doi.org/10.1146/annurev. ecolsys.39.110707.173430

Schraut G. 2000. - Eine neue Art von Scabrella (Trilobita) aus dem hohen Unter-Devon von Marokko. Senckenbergiana lethaea 79 (2): 435-440. https://doi.org/10.1007/BF03043648

SignOR P. W. III \& BRETT C. E. 1984. - The mid-Paleozoic precursor to the Mesozoic marine revolution. Paleobiology 10 (2): 229-245. https://doi.org/10.1017/S0094837300008174

ŠNAJDR M. 1981. - Bohemian Proetidae with malformed exoskeletons (Trilobita). Sborník Geologickćh věd. Paleontologie 24: 37-60.

SwARTZ F. M. 1925. - The Devonian fauna of Bolivia. Johns Hopkins University Studies in Geology 6: 29-68.

Thomas I. 1906. - Neue Beiträge zur Kenntnis der Devonischen Faunen Argentiniens. Zeitschrift der Deutschen geologischen Gesellschaft 57: 233-290. https://doi.org/10.5962/bhl.title.14071

UlRICH A. 1893. - Palaeozoische Versteinerungen aus Bolivien. Neues Jahrb Miner Geol Palaont Beil-Bd 8: 1-116.

VERMEIJ G. J. 2002. - Evolution in the consumer age: predators and the history of life. The Paleontological Society Papers 8: 375394. https://doi.org/10.1017/S1089332600001169

Vogdes A. W. 1890. - A bibliography of Paleozoic Crustacea from 1698 to 1889, including a list of North American species and a systematic arrangement of genera. U.S. Geological Survey Bulletin 63: 1-177. https://doi.org/10.3133/b63

Whittington H. B. \& Kelly S. R. A. 1997. — Morphological terms applied to Trilobita, in KAESLER R. L. (ed.), Treatise on Invertebrate Paleontology, Part O, Arthropoda 1, vol. 1, Boulder, Colorado, and Lawrence, Kansas. Geological Society of America and University of Kansas Press, Lawrence, Kansas: 313-329.

Willman S. 2007. - Testing the role of spines as predatory defense. Journal of Shellfish Research 26 (1): 261-266. https:// doi.org/br7rx3

WOlFART R. 1968. - Die Trilobiten aus dem Devon Boliviens und ihre Bedeutung für stratigraphie und tiergeographie, in Wolfart R. \& VogES A. (eds), Beiträge zur Kenntnis des Devons von Bolivien. Beihefte zum Geologischen Jahrbuch 74: 5-201. 